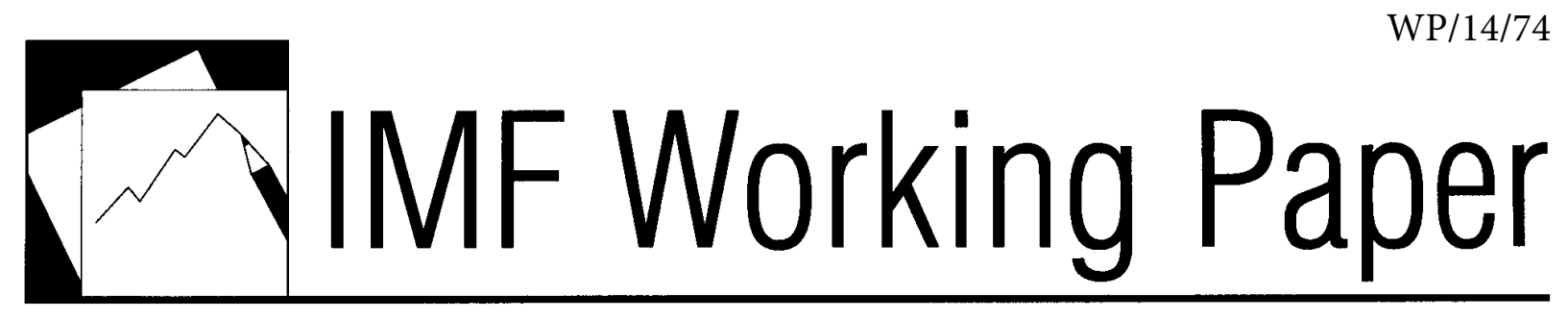

\title{
The Role of Country Concentration in the International Portfolio Investment Positions for the European Union Members
}

\author{
Iuliia Brushko and Yuko Hashimoto
}




\title{
IMF Working Paper
}

Statistics Department

\section{The Role of Country Concentration in the International Portfolio Investment Positions for the European Union Members}

\author{
Prepared by Iulia Brushko and Yuko Hashimoto ${ }^{1}$
}

Authorized for distribution by Robert York

April 2014

\section{This Working Paper should not be reported as representing the views of the IMF. The views expressed in this Working Paper are those of the author(s) and do not necessarily represent those of the IMF or IMF policy. Working Papers describe research in progress by the author(s) and are published to elicit comments and to further debate.}

\begin{abstract}
This paper examines the international portfolio flows of European Union. Our analysis includes three dimensions: (1) the level of countries' portfolio investment concentration (those who invest evenly among counterparties versus those who invest more heavily in some counterparties); (2) the share of total portfolio investment assets invested at the destination; and (3) pre- and during the crisis periods. We find that portfolio investment positions respond differently to macroeconomic variables depending on the level of investment concentration and the share of invested assets. In particular, variables of health of the financial system become important determinants for portfolio investment during the crisis.
\end{abstract}

JEL Classification Numbers:F21, G11, G15

Keywords: International Portfolio, Portfolio Flows, Portfolio Concentration

Authors’ E-Mail Addresses: ibrushko@,cerge-ei.cz, YHashimoto@imf.org

\footnotetext{
${ }^{1}$ The authors wish to thank Mohammed El Qorchi for his guidance and thank Steven Phillips, R.J. Walton, Alfredo Leone, Kimberly Zieschang, Mick Silver, Carlos Caceres, Jan Hanousek, Olga Popova, Anna Kochanova, colleagues from the IMF's European and Research Departments, and participants at the IMF Statistics Department brown bag seminar for constructive discussions and helpful comments. The paper was prepared when Ms. Brushko was an IMF summer intern. Any errors are solely the authors' responsibility.
} 


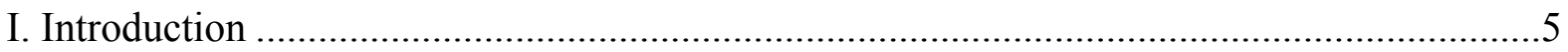

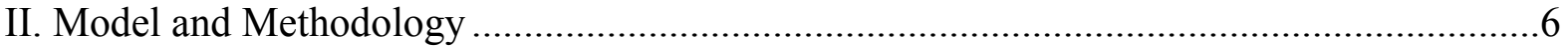

III. Data and Main Variables ........................................................................................ 11

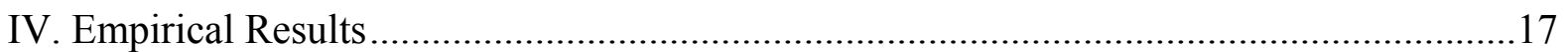

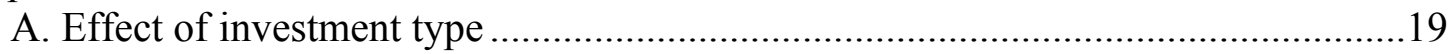

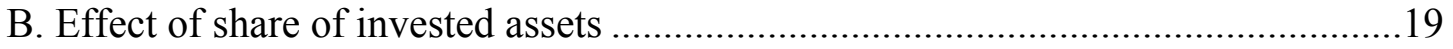

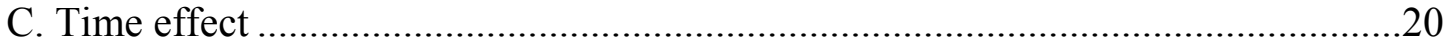

D. Policy implications and possible extensions ..............................................20

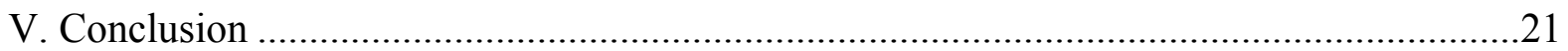

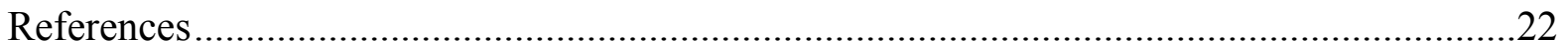

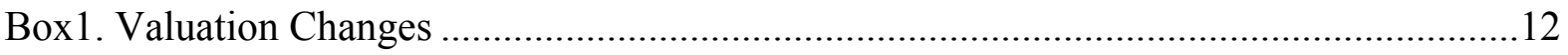

Tables

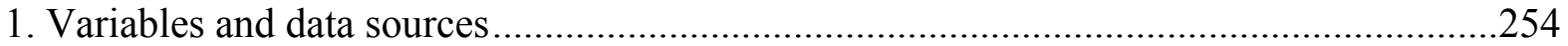

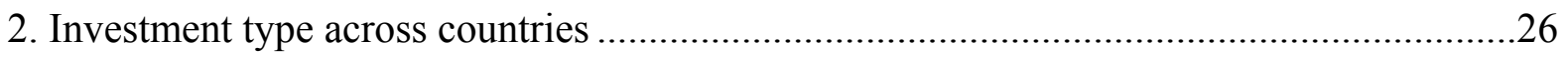

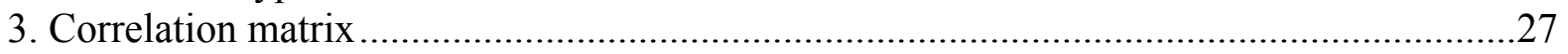

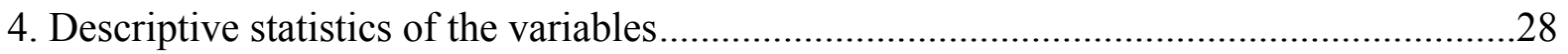

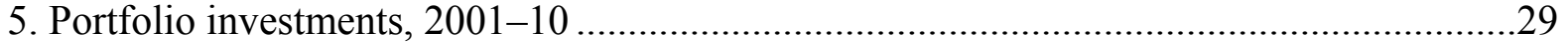

6. Portfolio investments, 2001-10, share below or equal to 1 percent ..................................29

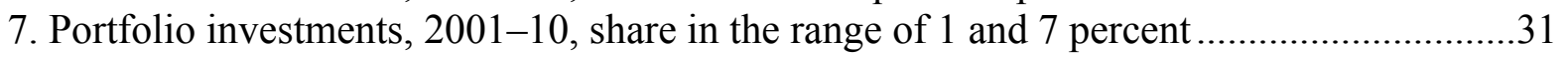

8. Portfolio investments, 2001-10, share equal to or above 7 percent ..................................32

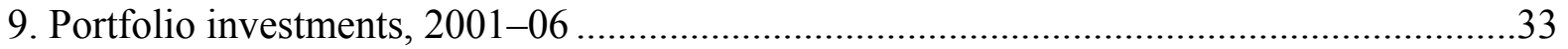

10. Portfolio investments, 2001-06, share below or equal to 1 percent ...............................34

11. Portfolio investments, 2001-06, share in the range of 1 and 7 percent ...........................35

12. Portfolio investments, 2001-06, share equal to or above 7 percent ................................36

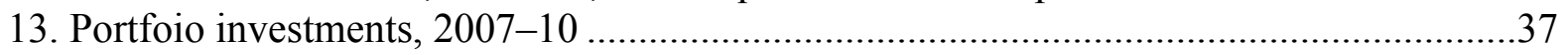

14. Portfolio investments, 2007-10, share below 1 percent ................................................38

15. Portfolio investments, 2007-10, share in the range of 1 and 7 percent ...........................39

16. Portfolio investments, 2007-10, share equal to or above 7 percent .................................39

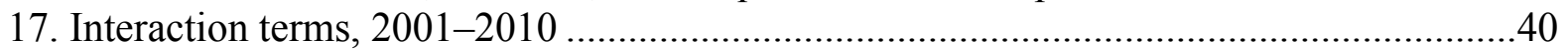

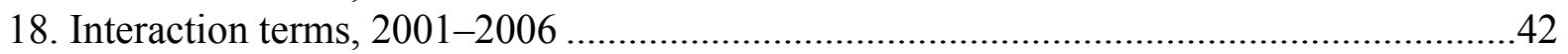

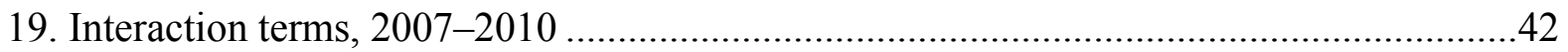


Figures

Figure 3: Time trend of concentration index ...

Figure 1. Standard deviation of returns on portfolio investments

Figure 4. The comparison of distributions of main variables before and during the crisis 15

Figure 4 (continued). The comparison of distributions of main variables before and

during the crisis. 16

Figure 2. The distribution of concentration index before and during the crisis 


\section{INTRODUCTION}

Although it is known that investing internationally provides opportunities for diversification, investors do not use these opportunities fully. Among the reasons they have cited for not doing so are information asymmetry, preferences for home assets, transaction costs, and high risk-aversion. All these factors determine international investors' motivation to invest abroad and, consequently, their investment strategies. Thus, for example, countries with higher risk aversion could be expected to diversify more, while countries with lower risk aversion might exploit more risky strategies by specializing more and forgoing the benefits of diversification. Home investors' preferences for the assets of a particular country also determine their investment behavior. It was also shown that changes in risk aversion and risk appetite during an economic slowdown have an impact on portfolio rebalancing $(\mathrm{Fu}, 1993$; Kumar and Persaud, 2001; Coudert and Gex, 2006; and Caceres et al., 2010).

Concentration may therefore play a crucial role in portfolio management. On the one hand, by forming more concentrated portfolios, investors may forgo the benefits of international diversification, ${ }^{2}$ on the other hand, they may enjoy an information advantage by investing in a limited set of assets (Kacperczyk et al., 2005; Ivkovic, 2008; and Huij and Dereall, 2009).

These findings suggest to us that different investment strategies are driven by different incentives for investing abroad. As the consequence of differences in the motivation to invest, one may expect correspondingly different responses to the same changes in the investment environment. Although there is an extensive literature on the relative benefits of diversification and concentration, studies are scarce on the specific question of how the choice of one or the other can explain changes in international portfolio investment positions. To fill this gap in the literature, the present study tries to determine whether an investment strategy matters for international investment reallocation. Investment strategy is characterized by two dimensions: investment type - low or high concentration - of the source countries; and investment share at the destination. Investment concentration measures the extent to which a source country has concentrated its investments; that is, a country that invests more evenly among many counterparties is considered a low-concentration country, whereas a country that invests heavily in only a few counterparties is considered a highconcentration country.

The investment share at the destination measures the proportion of a source country's total portfolio investment that is invested in the destination country. This measure highlights the importance and exposure of a source country to the destination countries. The hypothesis is that the investment type is driven by particular investment motives and considerations, while the second dimension (the share of the portfolio a country invests in a counterparty) might be determined more by investor's preferences for particular sectors, asset types, or a particular

\footnotetext{
${ }^{2}$ This point was expressed earlier by Grubel (1968), Levy and Sarnat (1970) and Solnik (1974), and then called into question by the increase in the correlation of assets returns by Butler and Joaquin (2001), Ang and Bekaert (2002), and Chesnay and Jondeau (2001). Nevertheless, Ang and Bekaert (2002), Khoury (2003), Driessen and Laeven (2004), Das and Uppal (2004), Flavin and Panopoulou (2006), and Santis and Sarno (2008) show that there are still benefits from international diversification.
} 
country. We expect that both of these factors (investment concentration and share) determine changes in portfolio positions. We also compare portfolio positions before and during the crisis. The portfolio positions could be affected considerably, especially during the crisis, because the risk-aversion rises (Guiso and Paiella, 2008) and the correlation of the asset returns across countries increases sharply during economic slowdowns (Forbes and Rigobon, 2002).

We contribute to the literature in several ways. First, we take into account macroeconomic conditions when investigating the country's portfolio positions and the level of uncertainty. Second, using the Coordinated Portfolio Investment Survey (CPIS) data, we look at the investment type (high- or low-concentration) and the investment share at the destination to identify the countries' portfolio investment decisions. Finally, we split the sample period into two - before and after the global financial crisis - to examine the impact of the crisis on portfolio investment positions.

The empirical results of this study suggest that investment type (concentration) plays a role in explaining changes in international portfolio investment positions. The results also show that low-concentration countries respond in the opposite direction relative to the highconcentration type: when the portfolio flows exhibit a negative reaction to the changes in the macro variables for the high-concentration type, the low-concentration type reaction to such variables is less negative or is positive; conversely, the positive reaction of the highconcentration type is accompanied by a less positive reaction of the low-concentration type. Moreover, the analysis reveals that the crisis changes the set of the variables that elicit these differing responses from the two types: before the crisis, the types mainly differ in their responses to the general macroeconomic conditions (GDP growth, CPI, unemployment, government debt, etc.), while during the crisis the types put different weights on the variables that can signal the health of the financial system (short- and long-term interest rates, stock index and stock index growth). We believe that our findings can help policymakers to predict and manage severe capital outflows that can occur when a country faces unexpected (exogenous) market liquidity shocks and contagion.

The paper is organized as follows. Section II introduces the methodology. The main variables and data sources are discussed in Section III. The main empirical results are discussed in Section IV. Section V concludes.

\section{Model ANd Methodology}

The main aim of this paper is to investigate the extent to which the international portfolio investments change depending on macroeconomic conditions. In our model we include both macroeconomic variables and the uncertainty of these macroeconomic variables in a given year, because uncertainty will have a crucial role for the international investment decision.

Our basic dynamic panel model of international portfolio investment positions is represented by equation (1).

$$
Y_{i, j, t}=\alpha+\rho Y_{i, j, t-1}+\beta^{\prime} X_{j, t}+\mu_{i, j}+\eta_{t}+e_{i, j, t}
$$


where subscripts $i, j$, and $t$ denote the country of origin, the country of destination, and time, respectively. $Y_{i, j, t}$ is the vector of dependent variables of either the logarithm of the ratio of total portfolio assets, equity securities, or debt securities, invested by country $i$ into country $j$ in year $t$ evaluated at the market value to GDP. $Y_{i, j, t-1}$ is the vector of the logarithm of the portfolio investment to GDP ratio in the previous year, and it is included into the estimation equation in order to take into account the persistence of the series. $X_{j, t}$ is the matrix of control variables for country $j$ in year $t$ and consists of the macroeconomic variables and their standard deviations listed in footnote $3 .^{3} \mu_{i, j}$ represents the vector of unobservable fixed effect between countries $i$ and $j$ such as culture, history, geography, economical or social interconnection. $\eta_{t}$ denotes the vector of common time-specific unobservable effects. $e_{i, j, t}$ is the vector of the error term with zero mean and constant variance.

In estimating equation (1), endogeneity problems will arise in our specification, as changes in the portfolio flows affect short- and long-term interest rates: the outflows move rates up because less funds are available for borrowing (i.e., the excess demand for money) and inflows move them down (Warnock and Warnock, 2009; Kuori and Porter, 1974), but changes in the short- and long-term interest rates also determine the decision to invest Through interest rates channels, other right-hand side macroeconomic variables are also influenced by changes in the portfolio flows. For example, changes in interest rates affect the government debt through the borrowing costs, making the government debt as an endogenous variable.

To overcome the endogeneity issues, we use the system dynamic panel GMM estimator developed by Arellano and Bond (1995) and extended by Blundell and Bond (1998). To solve the endogeneity problem, Arellano and Bond (1991) suggest using the lags, starting from the second one as instruments for the endogenous variables in the first difference equation. The system dynamic panel provides efficiency by estimating both the equations in levels and in the first differences. In the equation in the levels, the estimator uses the lags of first differences of the endogenous variables, while in the equation in differences, the second lag of the endogenous variables is used as an instrumental variable. For the lags and the lags of first differences of the variable to be the appropriate instruments for the endogenous variables, the following conditions should hold:

For the equation in levels:

$$
E\left[\Delta Y_{i, j, t-1}\left(\mu_{i, j}+e_{i, j, t}\right)\right]=0 \text { and } E\left[\Delta X_{i, j, t-1}\left(\mu_{i, j}+e_{i, j, t}\right)\right]=0
$$

\footnotetext{
${ }^{3}$ The list of control variables, $X_{j, t}$, is as follows: short-term interest rate and standard deviation of short-term interest rate, long-term interest rate and standard deviation of long-term interest rate, stock index and standard deviation of stock index, growth of stock index and standard deviation of stock index growth, unemployment rate and standard deviation of unemployment rate, growth of seasonally adjusted consumer price index and standard deviation of consumer price index growth, real effective exchange rate, GDP growth, the ratio of current account to GDP, and government debt to GDP ratio.
} 
For the equation in first differences:

$E\left[Y_{i, j, t-2} \Delta e_{i, j, t}\right]=0$ and $E\left[X_{j, t-2} \Delta e_{i, j, t}\right]=0$

for $t \geq 3 .^{4}$

For distinguishing high- and low-concentration types, we use the approach of Kacperczyk et al. (2007) who developed the industry concentration index. We calculate the concentration index according to the following formula:

$C I_{i, t}=\sum_{j}^{N}\left(\omega_{i, j, t}-\bar{\omega}_{j, t}\right)^{2}$

where $\omega_{i, j, t}$ is the share of total portfolio investment assets of country $i$ invested in country $j$ in year $t$ and $\bar{\omega}_{j, t}$ is the region average share of total portfolio investment assets invested in country $j .{ }^{6}$

The concentration index should reflect how the portfolio of a particular country deviates from the benchmark portfolio. The benchmark portfolio measures the average weights of invested assets in a destination country, and the time trend of concentration index is shown in Figure 1. There are two main reasons for using this index. First, the index is adjusted for a country's attractiveness for investments (i.e. if the country is perceived to offer better investment opportunities, the average weight of investments in this country will be higher). Second, it takes into account the time-varying optimal investment share. The second feature is currently especially topical, because we can observe the flight to quality and higher capital inflows into such countries as Germany and Unites States. Once the concentration index is calculated for all sample countries, the countries are classified either as a high- or lowconcentration group. Countries with concentration index equal to or higher than the 65th percentile are classified as the high-concentration type. The low-concentration investment types are those countries with the concentration index equal to or below the 35 th percentile. ${ }^{7}$

\footnotetext{
${ }^{4}$ Although the longer lags are also valid instruments in system GMM, we use only the first lag of differences in the level equation and the second lag of the endogenous variables in the difference equation. By doing this, we restrict the number of instrumental variables, since Roodman (2008) shows that even being valid separately, the large number of instruments can collectively be invalid because they may overfit endogenous variables.

${ }^{5}$ For calculating the average share of the region, we exclude such destinations marked in CPIS as "International Organizations + SEFER (CPIS)", "International Organizations", "Other Countries Confidential", and "Other Countries, not Specified".

${ }^{6}$ After merging different datasets and due to data limitations of some macro variables, the set of destination countries includes Australia, Austria, Belgium, Bulgaria, Canada, Hong Kong, Denmark, Finland, France, Germany, Hungary, Ireland, Israel, Italy, Japan, Netherlands, New Zealands, Norway, South Africa, Spain, Sweden, Switzerland, United Kingdom, and United States.

${ }^{7}$ For grouping low- and high-concentration types, we considered also approaches of dividing the sample based on the 25th and 75th percentiles, or the 30th and 70th percentiles, but our empirical results qualitatively do not change. In this study, we are presenting the results from grouping based on the principle of the 35th and 65th percentiles, since we believe such an approach is most objective: an average ("normal", "standard", or "representative") country will have the index within the 35th and 65th percentiles, while those countries which significantly differ from an average country will fall out of these bounds.
} 
In order to test whether high- and low-concentration types differ in their responses to the changes in the macroeconomic variables, we modify equation (1) and estimate equation (5):

$Y_{i, j, t}=\alpha+\rho Y_{i, j, t-1}+\beta^{\prime} X_{j, t}+\gamma^{\prime} d_{l o w} * X_{j, t}+\eta_{t}+e_{i, j, t}$

where $d_{\text {low }}$ is a dummy variable and equals 0 if the data come from the sub-sample of the high-concentration type and 1 if the data are for the sub-sample of the low-concentration type. If we find the estimates of $\gamma$ to be significant, this will provide evidence that these investment types differ in the responses to the macro variables. 
Figure 1. Time trend of concentration index by country

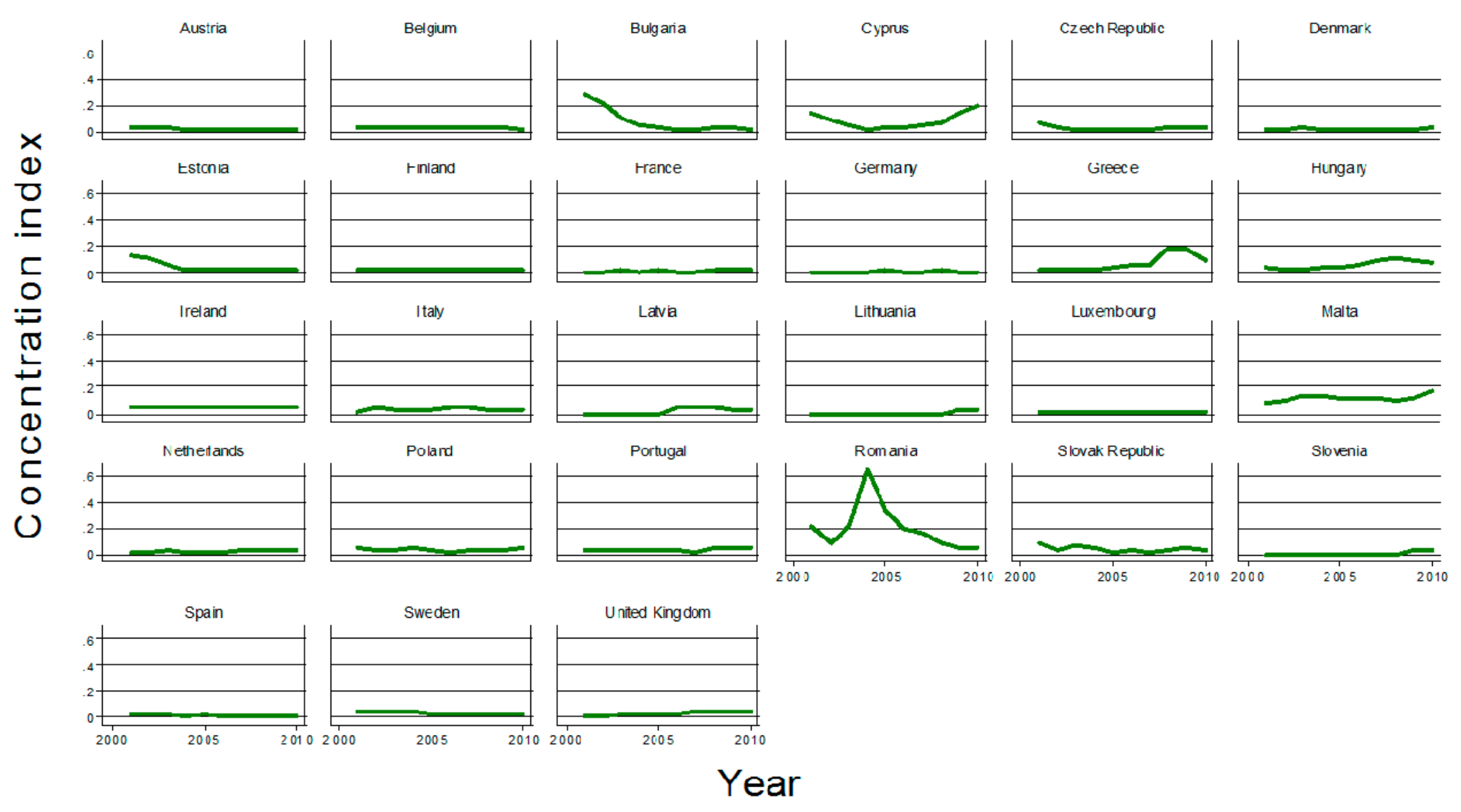




\section{DATA AND MAIN VARIABLeS}

The set of control macroeconomic variables includes short-term interest rate, long-term interest rate, stock index, growth of stock index, unemployment rate, the growth of seasonally adjusted consumer price index (inflation), real effective exchange rate, GDP growth, the ratio of current account to GDP, and government debt to GDP ratio. ${ }^{8}$ To take into account the uncertainty associated with the macro variables, we also include the standard deviations during a given year of such variables as short-term interest rate, long-term interest rate, growth of stock index, stock index, unemployment rate, and seasonally adjusted consumer price index growth.

We include the short-term interest rate because it can signal market liquidity (Bomfim, 2003; Chordia, 2000) and reveal the spread and the cost of offsetting the position by the security issuer or trader (Aiyagari and Gertler, 1999). The change in the short-term interest rate results in the profitability of the investment and subsequently in the motivation to invest in or withdraw from a country. Besides, a change in the short-term interest rate may be perceived as a change in monetary policy and an increase (decrease) in interest rates pushes stock prices and yields to maturities down (up) (Rigobon and Sachs, 2002), which results in portfolio outflows (inflows). The standard deviation of the short-term interest rate will proxy for the uncertainty of market liquidity.

Long-term interest rates are usually used by investors to discount the future cash flows that determine asset prices. That is why a change in the long-term interest rate results in asset price movements and capital gains or losses from the investments, while the volatility of long-term interest rates contributes to the risk of asset returns. Gagnon et. al. (2011) show that a decline in the long-term interest rate may signal a reduction in the risk premium which will also have an impact on portfolio withdrawals.

Because our dependent variable is the international portfolio investment position (investments in total portfolio investment assets, equity securities, or debt securities) at market value, we also include the change in the stock index which should control for the changes in the asset valuation as well as for the change in the position itself. The standard deviation of the stock index is used to control for the volatility of the asset prices. ${ }^{9}$

Investors' decisions to invest or disinvest are also influenced by the returns they earn from investing in a particular country (Brennan and Cao, 1997). Because we do not have the data on the returns, we use instead the growth of the stock index. The inclusion of the growth of the stock index is motivated by the fact that passive strategies are optimal and one cannot

\footnotetext{
${ }^{8}$ The data sources and construction of all the variables are provided in Table 1.

${ }^{9} \mathrm{We}$ are aware that bond indices are a better proxy for debt asset valuation changes, but data on bond indices are limited, which makes our sample too small and results in a biased result. On the other hand, the correlation between stock and bond prices was established by previous research and was shown to be time varying. Among the factors determining the sign of stock-bond return correlation (Andersson et al., 2008; Li, 2002; Chiang and $\mathrm{Li}, 2009$ ) are inflation expectations, stock market uncertainty, and interest rate. By including such variables as consumer price index and standard deviation of stock market, we control for the time varying component of stock and bond price comovements.
} 
outperform the market (Burton, 2003 and Monnier and Rulik, 2012). The standard deviation of the growth of the stock index will also be a proxy for the risk of returns.

\section{Box 1: Valuation Changes ${ }^{10}$}

In estimating the impact of international portfolio investment positions, it is important to separate valuation changes from actual changes in investment positions. Simply taking a difference of two time series end-period investment positions does not fully reveal information on country's investment strategy because these data include changes in asset prices (valuation changes). Asset price changes could mask the actual transaction values especially when the market is volatile and could make misleading interpretation of shift in investment positions. In order to measure valuation changes, detailed data such as asset type, maturity, and prices are necessary. However, it is difficult to make an accurate estimation of valuation changes mainly due to the lack of such data. The IIP and CPIS data provide information on the broad composition of assets held in the form of equity and debt securities, but they do not provide details such as maturity and currency. Also, data on returns and bond indices are limited. One way to handle valuation changes is to include macroeconomic variables that proxy volatility in estimation equations. Interpretations of these variables are as follows. First, considering valuation changes as noise in the market and inclusion of macroeconomic variables as control variables can separate out the noise. Second is to view asset prices as being part of the outcome of the portfolio allocation decision. When demand for a certain type of asset increases, its price goes up as a consequence of that portfolio choice, so that portfolio reallocation is achieved in part by valuation changes, rather than by actual flows. In this regard, it is assumed that the portfolio reallocation through valuation changes (exchange rate) is not the case for our sample countries because they share the same currency.

The bilateral data on the portfolio returns are not available, but the balance of payments provides the total income on the portfolio investment for a country. We construct a new variable, which is calculated as the yearly portfolio income divided by the assets at the end of the previous year, and call it the returns on assets. This variable should measure the profitability of countries' portfolio investments, while the standard deviation is supposed to signal the risk of the investments. Figure 2 depicts the relation between the standard deviation of returns and the concentration index. For both debt and equity securities, one might observe that the dispersion of standard deviation of returns on portfolio investments decreases with the increase in the concentration index. This may imply that lowconcentration countries may tolerate higher risk associated with investments.

\footnotetext{
${ }^{10}$ We would like to acknowledge the helpful advice from Steven Phillips which suggested raising the important issue of valuation changes.
} 
Figure 2. Standard deviation (SD) of returns on portfolio investments
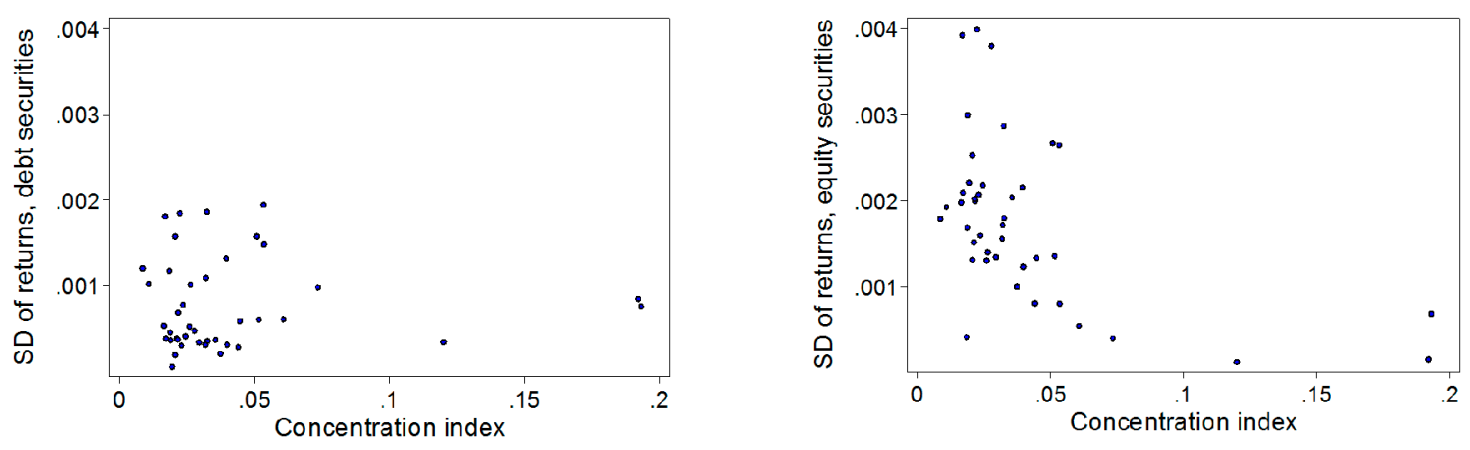

The unemployment rate is included as a leading indicator of stock performance, because the higher unemployment today implies lower GDP tomorrow and, as a result, lower stock returns (Flannery and Protopapadakis, 2002; Boyd et al., 2005); the standard deviation of the unemployment rate will also reflect the uncertainty of the stock performance. Inflation is included as a lagging indicator for the security analysis; the standard deviation of this variable should also take into account the risk of the asset returns.

We also include the government debt to GDP ratio as one of the explanatory variables. An increase in government debt drives up the demand for financing, which results in higher interest rates and consequently in higher borrowing costs, lower profit margins, and lower returns on assets. Moreover, an increase in the government debt motivates the government to increase the government bond supply which affects, as Maier (2006) shows, market liquidity and the returns that investors require.

In our analysis, we also use the time dimension because investing countries face different global macroeconomic conditions. We provide the evidence in Figure 3, which represents the comparison of distributions of the main variables used in the analysis before the crisis and after the crisis. As one would expect, the mass of distribution of short-term interest rate shifts towards the right, which implies that more of the destination countries were facing liquidity constraints that pushed the short-term interest rate upwards. What is interesting is that there was also a shift of the mass of the distribution to the left. We believe that could happen due to capital reallocation whereby some countries enjoyed capital inflows as the result of "flight-to-quality". This hypothesis can be also supported by the leftward shifts of the mass in the long-term interest rate, which can proxy for the yields on long-term government debt instruments. The increased demand for these instruments could push prices up and yields (long-term interest rate) downwards. These shifts also tell us that the countries became more heterogeneous in the level of short-term interest rates during the crisis.

We do not observe severe changes in the distributions of the unemployment rate, the stock index, and stock index growth; however, there is evidence of a slight increase in the dispersion of the stock index and a shift of mass in its growth, as expected, to the left during the crisis. On the contrary, the distributions of such variables as GDP growth, inflation, relative effective exchange rate, current account to GDP ratio, and government debt to GDP 
become more dispersed and flat, which also points to an increase in the heterogeneity in global macroeconomic conditions.

Figure 3 also gives evidence of an increase in all our measures of risk (except for the standard deviation of the stock index): there was a shift to the right in the mass of the distributions of such variables as the standard deviation of short-term and long-term interest rates, the standard deviation of stock index growth, the unemployment rate, and inflation. 

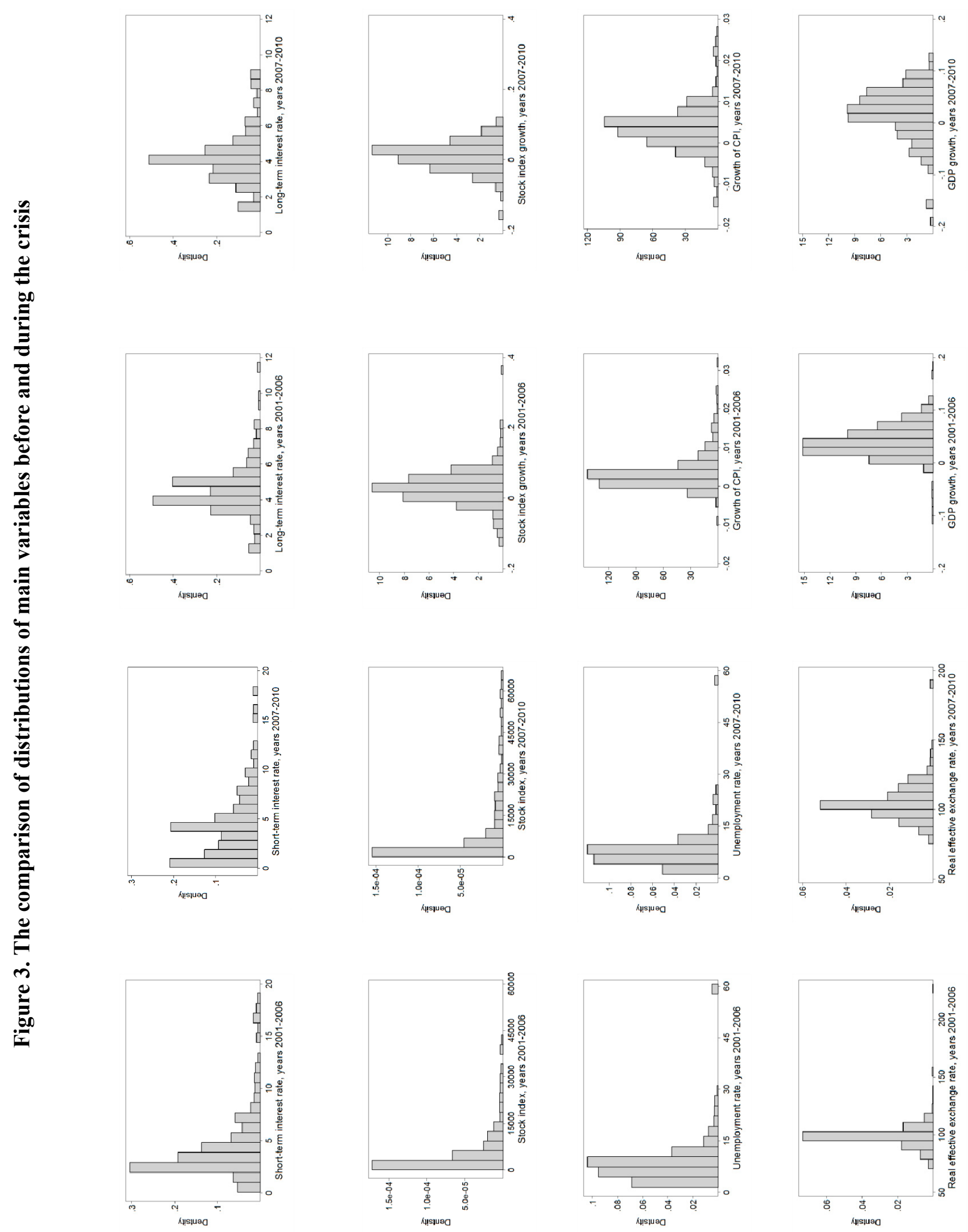

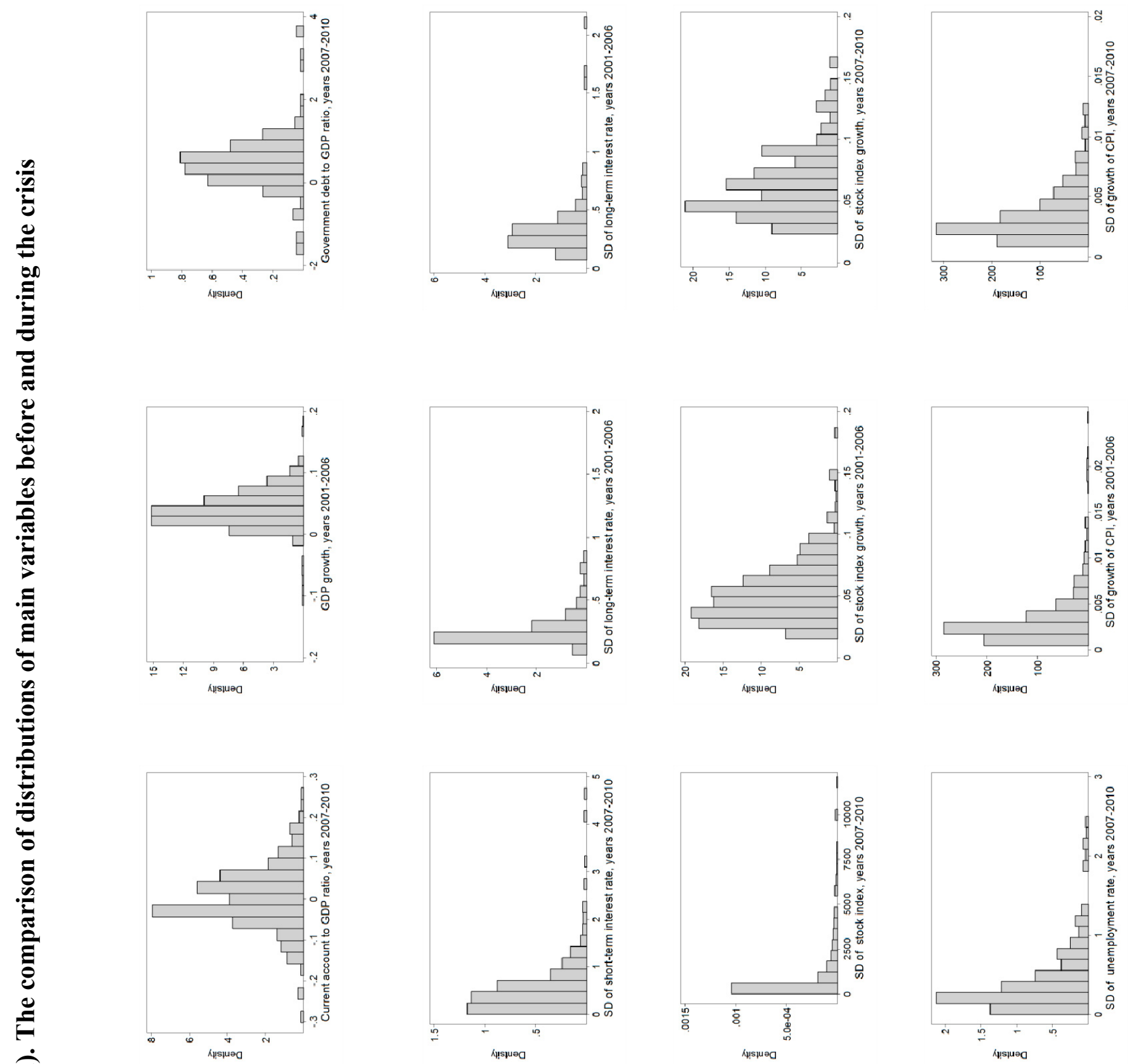

宅
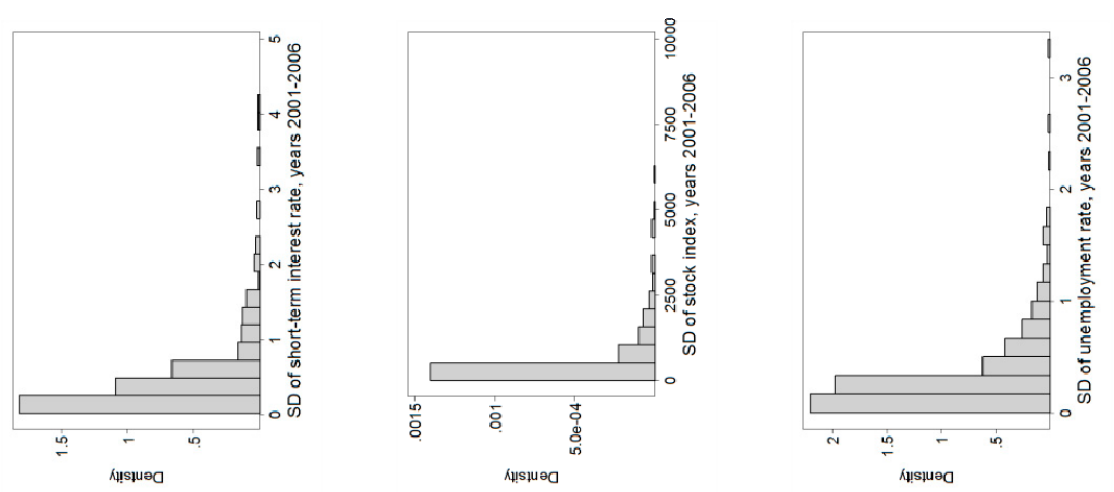
We use the data of the international investment positions from the CPIS, which are available on an annual basis over 2001 to 2010. The dataset provides bilateral cross-country data for individual countries, i.e. the international portfolio investment of country $i$ in country $j$, in addition to the global (aggregated) annual data. Data are available for the total portfolio investment positions and are also broken down by asset type: equity securities and debt securities. For debt securities, data are further classified into long- and short-term debt. The CPIS data provide two dimensions - the asset side and the liability side - for total portfolio assets, equity and debt securities. For both of the dimensions and for every concept, the CPIS contains two data entries. The asset side data represent residents' holding of securities issued by nonresidents (outward investment), i.e., portfolio investment by country $i$ in country $j$ is recorded as portfolio investment assets of country $i$. The liability side data include securities issued by residents and owned by nonresidents (inward investment), i.e., portfolio investment by country $j$ in country $i$ is recorded as portfolio investment liabilities of country $i$.

The dataset is unbalanced, and if there is a missing value for any of the variables, the missing values are substituted with the derived value if available. ${ }^{11}$ For our analysis, we focus on the portfolio investments of European Union members as the country-investors. The set of countries includes Austria, Belgium, Bulgaria, Cyprus, the Czech Republic, Denmark, Estonia, Finland, France, Germany, Greece, Hungary, Ireland, Italy, Latvia, Lithuania, Luxembourg, Malta, Netherlands, Poland, Portugal, Romania, the Slovak Republic, Slovenia, Spain, Sweden, and United Kingdom. We take the annual data on GDP, government debt, and current account balance from the World Economic Outlook database. From the Global Data Source dataset we take quarterly data of the short- and long-term interest rates, stock index, and unemployment rate. The quarterly data on seasonally adjusted CPI and relative effective exchange rates are taken from the IMF dataset.

\section{EMPIRICAL RESULTS}

The estimation results for the full sample period (2001-10) are presented in Table 5. The first three columns (columns 1, 2, and 3) of the table provide the estimates of equation (5), where the dependent variable is total portfolio investment assets, assets invested in equity securities, and assets invested in debt securities, respectively. The last three columns (columns 4, 5, and 6 ) are the estimates of $\gamma$ from equation (5).

Tables 6, 7, and 8 represent the estimation results of equation (5) for the full sample period but for the subset with the share of invested assets equal to or below 1 percent, in the range between 1 and 7 percent, and equal to or above 7 percent, respectively. Tables 9-12 provide the estimation results for years 2001-06 using the full sample, and the sub-samples with the share of invested assets below or equal to 1 percent, between 1 and 7 percent, and equal or above 7 percent, respectively. The estimation results for the sample years 2007-10 for the full sample, and with share of invested assets less or equal to 1 percent, in the range of 1 and 7 percent, respectively, and equal to or above 7 percent, are presented in Tables 13-16. We

\footnotetext{
${ }^{11}$ If country $i$ does not report its investment in county $j$, but country $j$ reports country's $i$ investment in country $j$ (this is country's $i$ assets at the value derived), the missing value on the asset side of country $i$ (due to nonreporting) is substituted with the data reported by country $j$.
} 
also provide the map for the significant $\gamma$ and their signs for the full sample period, for years 2001-06, and for years 2007-10, respectively, in Tables 17, 18, and 19.

The estimation results can be summarized as follows. First, the investment type determines the changes in international portfolio investment positions in response to the changes in the macroeconomic variables. Whenever the estimates are negative for the high-concentration type, they are less negative or positive for the low-concentration type, and, vice versa: whenever the estimates are positive for the high-concentration type, they are less positive or negative for the low-concentration type. We find that the share of invested assets also triggers different responses to the changes in the macro variables: on average, there are more differences in the responses for the sub-samples with shares smaller than 7 percent. The time dimension also plays a role: the low and high-concentration types differ in the responses to the macro variables in the pre-crisis and during the crisis period, but the sets of the variables in which they differ are not the same in the pre-crisis and crisis periods.

Figure 4. The distribution of concentration index before and during the crisis
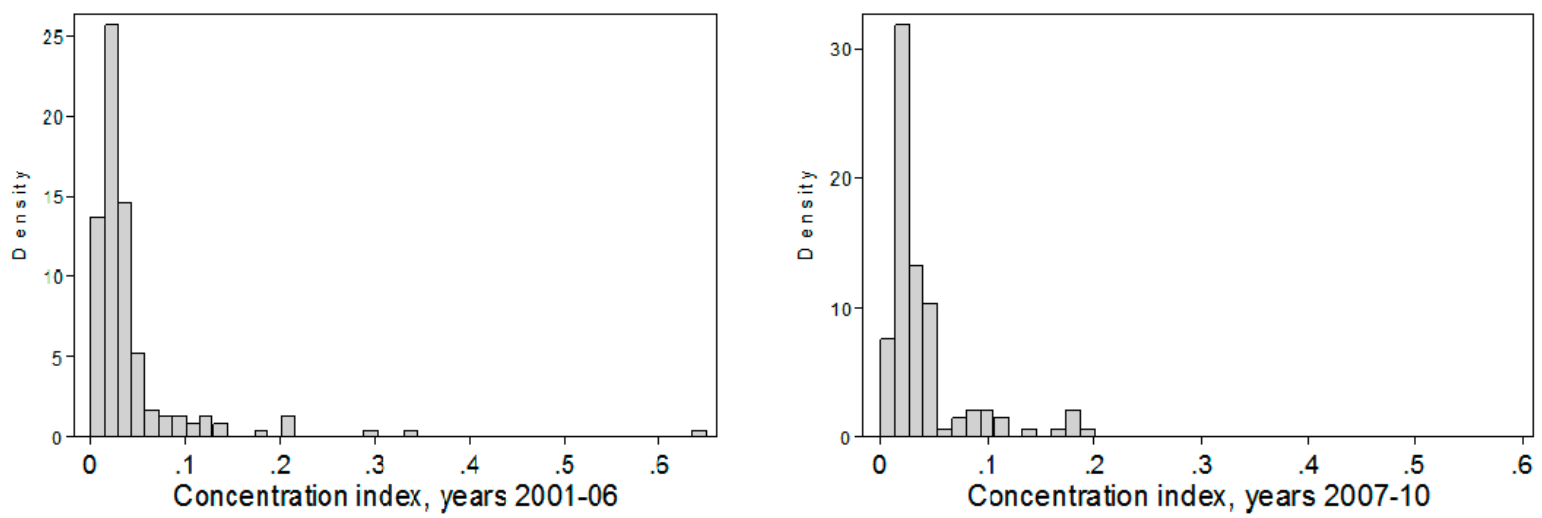

Figure 4 supports the results of the differences in the responses to the crisis during the crisis period. The figure on the left shows the distribution of the concentration index before the crisis, while the figure to the right shows the distribution of the concentration index during the crisis. The distribution becomes less skewed to the right during the crisis, which means that the concentration index became less dispersed. On the other hand, we can also observe the shift of the mass of the distribution a bit to the right. By the construction of the concentration index, the rightward shift may happen if the countries re-allocated their portfolios employing different investment strategies and deviating more from the mean region portfolio. ${ }^{12}$

\footnotetext{
${ }^{12}$ Our investment type measure (or concentration index) is time-dependent. Depending on the concentration types, we can distinguish five kinds of country-investors: 1) a country that before and during the crisis is high type; 2) a country that before and during the crisis is low type; 3 ) a country that is high type before the crisis, but low type during the crisis; 4) a country that is low type before the crisis, but high type during the crisis; 5) a country that changes its type in both pre-crisis and crisis periods. The classification of countries according to this principle is provided in Table 2.
} 


\section{A. Effect of Investment Type}

From the estimation of equation (5) with the full sample (Table 5), we find that the responses of high-concentration type and low-concentration type are different to variables that represent economic growth. ${ }^{13}$ The variables include stock index and growth of stock index, inflation and standard deviation of inflation, real effective exchange rate, GDP growth, debtto-GDP ratio, and standard deviation of long-term interest rate. In particular,

- The stock index is significant and negative for the high-concentration type, while the interaction term is positive for the low-concentration type. This implies that the lowconcentration type reacts more positively to a stock index rise.

- The estimate of the growth of the stock index is significant and positive (for equity securities) but the interaction term is significant and negative (for debt securities). This suggests that the low-concentration type reallocates the portfolio more slowly in response to an increase in the growth of the stock index.

We did the same comparison analysis for the sub-samples with different shares of invested assets and across time dimension.

- The low-concentration type countries tend to under-react or react in the opposite direction relative to the reactions of the high-concentration type countries.

\section{B. Effect of Share of Invested Assets}

Comparing Tables 6, 7, and 8 for the full sample (2001-10) we see that the share of assets invested plays a role in determining differences in portfolio investment allocatin between the concentration types. Countries with relatively low shares of invested assets tend to consider risk factors as key determinants for their portfolio investment, whereas those with high shares of invested assets take into account both risk and growth factors in their portfolio investment decisions.

- For the sub-sample with the share of invested assets equal to or below 1 percent, key variables of sources for differences in asset allocation decision are those that measure risks, such as standard deviation of the long-term interest rate, standard deviation of the stock index, and standard deviation of inflation, as well as long-term interest rate.

- For the sub-sample with the share of invested assets above 1 percent and below 7 percent, key determinants of portfolio investment decisions are those related to growth: short- and long-term interest rates, stock index growth, inflation, real effective exchange rate, GDP growth, and current account to GDP ratio.

\footnotetext{
${ }^{13}$ A significant $\gamma$ in equation (5) imply that the responses to variables differ for the types, as responses of highconcentration type countries are captured by $\gamma$ and those of low-concentration types equal to $(\beta+\gamma)$.
} 
- For the sub-sample with the share of assets invested equal to or above 7 percent, both risk and growth factors play a role as determinants of portfolio investment. Those significantly estimated variables include long-term interest rate, growth of stock index, real effective exchange rate, GDP growth, standard deviation of stock index and stock index growth, and standard deviation of unemployment rate.

\section{Time Effect}

The estimations for the pre-crisis period (2001-06, Tables 9-12) and during the crisis years (2007-10, Tables 13-16) show slightly different results for the determinants of portfolio investment.

- For the pre-crisis period, in general, variables that reflect macroeconomic condition are key determinants such as inflation, unemployment, real effective exchange rate, current account to GDP ratio, government debt to GDP ratio, and standard deviation of unemployment rate.

- During the crisis period, variables which are informative about the profitability of financial instruments and the health of the financial system play a key role such as shortand long-term interest rates, stock index and stock index growth, standard deviation of long-term interest rate, standard deviation of stock index and stock index growth.

\section{Policy Implications and Possible Extensions}

Combining all the findings, we should stress the importance for policymakers of understanding what types of investors the country attracts. Because the international portfolio inflows may move in different directions depending on the different types of countryinvestors, we may expect that those destination countries that have both types of investors (high- and low-concentration) may benefit from these differences. On the other hand, we may expect that destination countries with only one type of investors may suffer from a severe capital outflow.

Consider a scenario in which a country has a high proportion of low-concentration type country-investors. If a crisis or shock hits the economy and the main macroeconomic variables exhibit higher than average volatility, it may trigger the withdrawal of capital by low-concentration countries. This itself may create an additional severe impact on the macro variables and lead to capital flight spiral. On the other hand, the high-concentration type tends to be more tolerable to risk factors. If the country has both types of investors, the severe effect initiated by one type may be offset by the different behavior in the response to macro variable changes of the other type.

These arguments suggest that one of the possible extensions could be to test whether there is an asymmetry in financial stability during the crisis between those countries that had only high-concentration type investors versus those who had only the low-concentration type investors, and those who had both types. The second possible extension is to analyze which type of country-investors introduces more volatility to the market and accelerates financial 
contagion. This research will help to understand further the development of the international portfolio investment positions during the run-up to and during the crisis.

\section{Conclusion}

This paper argues that investment type matters in international portfolio capital flows. We find evidence that the international portfolio investments of high-concentration countries (which invest heavily in a particular subset of countries) and low-concentration countries (which invest in a broader set of countries) respond differently to changes in macro variables. This fact can be driven by differences in the investment strategies adopted. For example, high-concentration investment type countries may look for more profitable opportunities and are more inclined to tolerate risk in anticipation of earning higher returns. Low-concentration investment type countries, on the other hand, may look for diversification in the first place. As the strategies and motives are different, one could expect different responses to changes in the macroeconomic environment.

There is also evidence that the differences in responses depend on the share of invested assets in the country of destination. We explain this finding by the fact that the share will play a different role in the portfolio of different types of country investors. For example, the countries with a high share of invested assets are strategically important for the highconcentration investment type because they represent the core of their portfolio. In contrast, for the low-concentration type countries, the potential risk coming from the countries with a high share of invested assets may be offset by diversified investments.

Finally, the differences in responses to changes in macroeconomic variables are especially important during the crisis period: the two types of countries differ in both pre-crisis and crisis periods, but the set of variables in which they differ are different for both of these periods. 


\section{REFERENCES}

Aiyagarin, S.R. and Gertler, M. (1999). “ "Overreaction” of Asset Prices in General Equilibrium”, Review of Economic Dynamics, 2, pp. 3-35.

Ang, A., and Bekaert, G. (2002). (2002). "International Asset Allocation with Regime Shifts", Review of Financial Studies, 15 (4), pp. 1137-1187.

Andersson, M., Krylova, E. and Vahamaa, S. (2008). "Why Does the Correlation between Stock and Bond Returns Vary over Time?", Applied Financial Economics, 18 (2), pp. 139-151. Available at SSRN: http://ssrn.com/abstract=1740666

Arellano, M. and Bond, S. (1991). "Some Test of Specification for Panel Data: Monte Carlo Evidence and an Application to Employment Equations", Review of Economic Studies, 58, pp. 277-297.

Blundell, R. and Bond, S. (1998). "Initial Conditions and Moment Restrictions in Dynamic Panel Data Models", Journal of Econometrics, 87, pp. 397-415.

Bomfim, A. (2003). "Interest Rates as Options: Assessing the Markets' View on the Liquidity Trap", Finance and Economics Discussion Series, 2003-45.

Boyd, J.H., Hu, J. and Jagannathan, R. (2005). “The Stock Market's Reaction to Unemployment News: Why Bad News Is Usually Good for Stocks", Journal of Finance, vol. 60 (2), pp. 649-672.

Brennan, M.J. and Cao, H.H. (1997). "International Portfolio Flows", Journal of Finance, LII (5), pp. 1851-1880.

Burton, G.M. (2003). "Passive Investment Strategies and Efficient Markets", European Financial Management, 9 (1), pp.1-10.

Butler, K. C. and Joaquin, D. C. (2001). "Are the Gains from International Portfolio Diversification Exaggerated? The Influence of Downside Risk in Bear Markets", EFMA 2002 London Meetings. Available at SSRN: http://ssrn.com/abstract=221992

Caceres, C., Vincenzo, G. and Segoviano, M. (2010). "Sovereign Spreads: Global Risk Aversion, Contagion or Fundamentals?”, IMF Working Paper 10/120 (Washington: International Monetary Fund).

Chesnay, F. and Jondeau, E. (2001). "Does Correlation Between Stock Returns Really Increase During Turbulent Period?”, Economic Notes, vol 30(1), pp.53-80.

Chiang, T.C. and Li, J. (2009). "The dynamic Correlation between Stock and Bond Returns: Evidence from the U.S. Market". Available at SSRN: http://ssrn.com/abstract=1362225 or http://dx.doi.org/10.2139/ssrn.1362225. 
Chordia, T., Roll, R., and Subrahmanyam, A. (2001). "Market Liquidity and Trading Activity", Journal of Finance, 56(2), pp.501-530.

Coudert, V., and Gex, M. (2006). “Can Risk Aversion Indicators Anticipate Financial Crises?”, Financial Stability Review, 9, pp. 67-87.

Guiso, L. and Paiella, M. (2008). "Risk Aversion, Wealth, and Background Risk", Journal of the European Economic Association, 6(6), pp. 1109-1150.

Das, S.R. and Uppal, R. (2004). "Systemic Risk and International Portfolio Choice", Journal of Finance, LIX (6), pp. 2809-2834.

Driessen, J. and Laeven, L. (2007). "International Portfolio Diversification Benefits: CrossCountry Evidence from a Local Perspective", Journal of Banking and Finance, vol. 31(6), pp. 1693-1712.

Flavin, T. and Panopoulou, E. (2006). "International Portfolio Diversification and Market Linkages in the Presence of Regime-switching Volatility", IIIS Discussion Paper 167 (Florida: International Institute of Informatics and Systemics).

Flannery, M.J. and Protopapadakis, A.A. (2002). "Macroeconomic Factors Do Influence Aggregate Stock Returns”, Review of Financial Studies, vol. 15(3), pp. 751-782.

Forbes, K.J. and Rigobon, R. (2002). "No Contagion, only Interdependence: Measuring Stock Market Comovements", Journal of Finance, LVII (5), pp. 2223-2261.

Fu, J. (1993). “Increased Risk Aversion and Risky Investment”, Journal of Risk and Insurance, 60 (3), pp. 494-501.

Gagnon, J., Raskin, M., Remache, J., and Sack, B. (2011). "The Financial Market Effects of the Federal Reserve's Large-scale Asset Purchases”, International Journal of Central Banking, 7(1), pp. 3-43.

Grubel, H. (1968). "Internationally Diversified Portfolios: Welfare Gains and Capital Flows", American Economic Review, 58, pp. 89-94.

Huij, J. and Derwall, J. (2009). "Global Equity Fund Performance, Portfolio Concentration, and the Fundamental Law of Active Management", ERIM Report Series Reference. Available at SSRN: http://ssrn.com/abstract $=1456352$

Ivkovic, Z., Sialm, C., and Weicbenner, S. (2008). "Portfolio Concentration and the Performance of Individual Investors", Journal of Financial and Quantitative Analysis, 43 (3), pp. 613-656. 
Kacperczyk, M., Sialm, C., and Zheng, L. (2005). "On the Industry Concentration of Actively Managed Equity and Mutual Funds”, Journal of Finance, LX(4), pp. 1983-2011.

Khoury, S.J. (2003). "Country Risk and International Portfolio Diversification for the Individual Investor”. Financial Services Review, 12, pp. 73-93

Kumar, M.S. and Persaud, A. (2001). "Pure Contagion and Investors' Shifting Risk Appetite: Analytical Issues and Empirical Evidence", IMF Working Paper 01/134 (Washington: International Monetary Fund).

Kuori, J.K., and Porter, M.G. (1974). "International capital Flows and Portfolio Equilibrium”, Journal of political Economy, vol. 82 (3), pp.443-467.

Levy, H., and Sarnat, M. (1970). "International Diversification of Investment Portfolios", American Economic Review, 60, 668-75.

Li, L. (2002). "Macroeconomic Factors and the Correlation of Stock and Bond Returns", Yale ICF Working Paper No. 02-46; AFA 2004 San Diego Meetings. Available at SSRN: http://ssrn.com/abstract $=363641$

Maeirs, S. (2006). "Evidence on the Liquidity Effect in Euro Area Government Bond Markets - A Bayesian VAR Analysis", Unicredit and Universities WP 06.

Monnier, B. and Rulik, K. (2012). "Efficient Portfolio: Market Beta and Beyond”, ETFs and Indexing, 1, pp. 68-80.

Rigobon, R. and Sack, B. (2004). “The Impact of Monetary Policy on Asset Prices". Journal of Monetary Economics, 51 (8), pp. 1553--1575.

Roodman, D. (2008). “A Note on the Theme of Too Many Instruments”. Working Paper 125, Center for Global Development (Washington).

Roodman, D. (2009). "How to do xtabond2: An Introduction to Difference and System GMM in Stata", Stata Journal, 9 (1), pp. 86-136.

Santis, R. A. D. and Sarno, L. (2008). "Assessing the Benefits of International Portfolio Diversification in Bonds and Stocks", Working Paper Series 883, (Frankfurt: European Central Bank).

Solnik, B. (1974). “An Equilibrium Model of the International Capital Market”, Journal of Economic Theory, 4, pp. 500-524.

Warnock, F.E. and Warnock, V.C. (2009). "International Capital Flows and U.S. Interest Rates", Journal of International Money and Finance, 28, pp.903-919. 
Table 1. Variables and data sources

\begin{tabular}{|c|c|c|}
\hline Variable & Description & Source \\
\hline Dependent variable & $\begin{array}{l}\text { Log of either total portfolio investment assets, or equity } \\
\text { assets, or debt assets to GDP ratio for year } t\end{array}$ & CPIS \\
\hline $\begin{array}{l}\text { Portfolio investment } \\
\text { position }\end{array}$ & $\begin{array}{l}\text { Lag of dependent variable, i.e. lof of total portfolio } \\
\text { investment assets, or equity securities, or debt securities } \\
\text { to GDP ratio in year } t-1\end{array}$ & CPIS \\
\hline Short-term interest rate & $\begin{array}{l}\text { Average short-term interest rate in year } t \text {, percent per } \\
\text { annum }\end{array}$ & GDS \\
\hline Long-term interest rate & $\begin{array}{l}\text { Average long-term interest rate in year } t \text {, percent per } \\
\text { annum }\end{array}$ & GDS \\
\hline Stock index & Average benchmark stock index in year $t$ & GDS \\
\hline Growth of stock index & $\begin{array}{l}\text { Log of the ratio of annual average stock index in year } t \text { to } \\
\text { annual average stock index in year } t-1\end{array}$ & GDS \\
\hline Unemployment rate & Average unemployment rate in year $t$, percentae points & GDS \\
\hline CPI growth & $\begin{array}{l}\text { Average logarithm of the ratio of seasonally adjusted } \\
\text { consumer price index in the quarter to the consumer price } \\
\text { index in the quarter to the consumer price index inn the } \\
\text { previous quarter index in year } t\end{array}$ & $\mathrm{IMF}$ \\
\hline $\begin{array}{l}\text { Real effective exchange } \\
\text { rate }\end{array}$ & Average real effective exchange rate in year $t$ & IMF \\
\hline GDP growth & Log of real GDP in year $t$ to real GDP in year $t-1$ & WEO \\
\hline $\begin{array}{l}\text { Current account of GDP } \\
\text { ratio }\end{array}$ & Current account balance to GDP ratio in current prices & WEO \\
\hline $\begin{array}{l}\text { Government debt to GDP } \\
\text { ratio }\end{array}$ & The ratio of government debt to GDP in current prices & WEO \\
\hline $\begin{array}{l}\text { SD of short-term interest } \\
\text { rate }\end{array}$ & $\begin{array}{l}\text { Standard deviation over the year of quarterly short-term } \\
\text { interest rate in year } t\end{array}$ & GDS \\
\hline $\begin{array}{l}\text { SD of long-term interest } \\
\text { rate }\end{array}$ & $\begin{array}{l}\text { Standard deviation over the year of quarterly long-term } \\
\text { interest rate }\end{array}$ & GDS \\
\hline SD of stock index & $\begin{array}{l}\text { Standard deviation over the year of quartely benchmark } \\
\text { stock index in year } t\end{array}$ & GDS \\
\hline SD of stock index growth & $\begin{array}{l}\text { Standard deviation over the year of quarterly benchmark } \\
\text { stock index growth in year } t\end{array}$ & GDS \\
\hline SD of unemployment rate & $\begin{array}{l}\text { Standard deviation over the year of quarterly } \\
\text { unemployment rate in year } t\end{array}$ & GDS \\
\hline SD of CPI growth & Standard deviation over the year of CPI growth in year $t$ & IMF \\
\hline
\end{tabular}

CPIS - Coordinated Portfolio Investment Survey

WEO_-World Economic Outlook

GDS - Global Data Source 
Table 2. Investment type across countries

\begin{tabular}{|l|l|}
\hline $\begin{array}{l}\text { A country that always stays high- } \\
\text { concentration type }\end{array}$ & $\begin{array}{l}\text { A country that always stays low-concentration } \\
\text { type }\end{array}$ \\
Cyprus & Denmark \\
Hungary & Germany \\
Ireland & Finland \\
Malta & France \\
Portugal & Lithuania \\
Romania & Luxembourg \\
Spain & Netherlands \\
& Slovenia \\
\hline $\begin{array}{l}\text { A country that is high-concentration type } \\
\text { before the crisis and low-concentration type } \\
\text { during the crisis }\end{array}$ & $\begin{array}{l}\text { A country that is low-concentration type } \\
\text { before the crisis and high-concentration type } \\
\text { during the crisis }\end{array}$ \\
Belgium & None \\
Bulgaria & \\
Sweden & \\
\hline
\end{tabular}

\section{A list of countries that changes their type both during pre-crisis and crisis periods}

Austria: low type - years: 2004, 2005, 2007, 2008, 2009, and 2010

high type - years: 2003

Czech Republic: low type - years: 2003, 2004, 2005, and 2006

high type - years: 2001, 2002

Estonia: low type - years: 2006

high type - years: 2001, 2002, and 2003

Greece: low type - years: 2001, 2002, and 2003

high type before and during the crisis

Italy: low type - years: 2001, 2009, and 2010

high type - years: 2002, 2004, 2006, and 2007 before and during the crisis

Latvia: low type - years: 2001, 2002, 2003, 2004, 2005, and 2010

high type - years: 2006, 2007, and 2008

Poland: low type - years: 2006

high type - years: 2001, 2004, 2005, 2007, 2009, and 2010

Slovak Republic: low type - years: 2007

high type - years: 2001, 2002, 2003, 2004, 2008, 2009, and 2010

United Kingdom: low type - years: 2001, 2002, and 2003

high type - years: 2005, 2006, 2007, 2008, 2009, and 2010 
Table 3. Correlation matrix

\section{VARIABLES}

$\log$ of total assets to GDP

$\log$ of equity securities to GDP

$\log$ of debt securities to GDP

short-term interest rate

long-term interest rate

stock index

growth of stock index

unemployment rate

CPI growth

real effective exchange rate

GDP growth

current account to GDP

government debt to GDP

SD of short-term interest rate

$\mathrm{SD}$ of long-term interest rate

SD of stock index growth

SD of stock index

SD of unemployment rate

SD of CPI growth

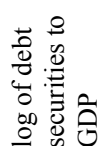

응

1.00

$0.85 * * *$

$0.93 * * *$

$-0.11 * *$

$0.03 *$

$-0.08 * * *$

$-0.01$

$-0.05 * * *$

$-0.07 * * *$

$-0.08 * * *$

$-0.07 * *$

$-0.05 * * *$

$0.03 * * *$

$-0.07 * * *$

0.00

$-0.06 * * *$

$-0.08$

$-0.03$

$-0.06$

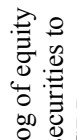
2.

1.00
$0.66 * * *$
$-0.08^{* * *}$
-0.01
$-0.05 * * *$
$0.02 * *$
$-0.04 * * *$
$-0.06 * * *$
$-0.04 * * *$
$-0.02 * *$
-0.00
$0.05 * * *$
$-0.05 * * *$
-0.00
$-0.07 * * *$
$-0.06 * * *$
$-0.04 * * *$
$-0.07 * * *$

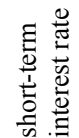

क.$\Xi$

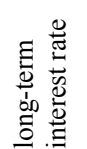

으.
1.00

$-0.11 * * *$

$0.05 * *$

$0.71 * * *$

$-0.03 * * * \quad 0.05 * * *$

$-0.05 * * *$

$-0.08 * * *$

$-0.09 * * *$

$-0.06 * * *$

$-0.09 * *$

$0.03 * * *$

$-0.07 * * *$

0.00

$-0.05 * * *$

$-0.09 * * *$

$-0.01 *$

$-0.05 * * *$
$0.17 * * *$

$0.045 * * *$

0.00

$-0.02 * *$

$-0.07 * * *$

$0.43 * * *$

$0.75 * * *$

$0.16 * * *$

$0.33 * * *$

$0.31 * * *$

$0.22 * * *$

0.48
1.00

$0.18 * * * \quad 1.00$

$-0.07 * * * \quad 0.02 * *$

$0.51 * * *$

$0.21 * * *$

$-0.18 * * *$

0.01

$-0.38 * * *$

$-0.02 *$

$0.46 * * *$

$0.045 * * *$

$0.13 * * *$

$0.25 * * *$

$0.38 * * *$

$0.05 * * *$
$0.02 * *$
$0.13 * * *$

$0.15 * * *$

$0.22 * * *$

$0.04 * * *$

$-0.10 * * *$

$0.44 * * *$

$0.04 * * *$

$0.02 *$

$-0.01 * *$

$0.73 * * *$

$0.09 * * *$

$0.01 *$
1.00

$\quad 1.00$

$0.34 * * * \quad 0.09 * * *$

$-0.10 * * *$

$0.06^{* * *}$

$0.08 * * *$

$0.05 * * *$

$0.06^{* * *}$

$-0.12 * * *$

$-0.33 * * *$

$-0.01$

$0.09 * * *$

$0.04 * * *$
$0.09 * * *$
-0.01

$0.06^{* * *}$

$-0.16 * * *$

$0.18^{* * *}$

$0.13 * * *$

$0.22 * * *$

$0.15^{* * *}$

$0.15^{* * *}$

$0.22 * * *$

$0.14 * *$
1.00

$0.02 * * *$

$0.19 * * *$

0.01

$0.11^{* * *}$

$0.25^{* * *}$

$0.04 * * *$

$0.02 * * *$

$0.10^{* * *}$

0.01

$0.25^{* * *}$

$* * * p<0.01, * * p<0.05 * p<0.1$

Table 3 (continued). Correlation matrix

\begin{tabular}{|c|c|c|c|c|c|c|c|c|c|}
\hline VARIABLES & 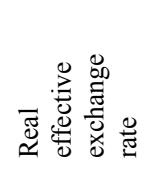 & 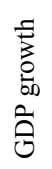 & 莺兽 & 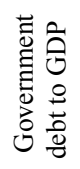 & 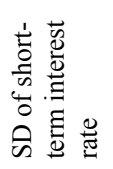 & 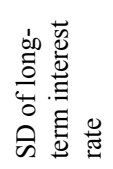 & 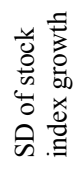 & 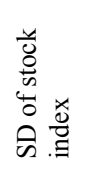 & 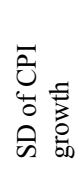 \\
\hline
\end{tabular}

real effective exchange rate GDP growth current account to

GDP

government debt

to GDP

SD of short-term

interest rate

SD of long-term

interest rate

SD of stock index

growth

SD of stock index

$\mathrm{SD}$ of

unemployment

rate

$\mathrm{SD}$ of CPI growth
1.00

$-.04 * * * \quad 1.00$

$-0.04 * * * \quad 0.04 * * * \quad 1.00$

$\begin{array}{llll}-0.02 * * & -0.10 * * * & -0.33 * * * & 1.00\end{array}$

$0.07 * * *$

$-0.22 * * * \quad 0.02 * *$

0.33

1.00

$0.06 * * *$

$-0.09 * * * \quad-0.15 * * *$

$0.15 * * *$

$0.22 * * *$

1.00

$0.12 * * *$

$-0.26 * * * \quad-0.10 * * *$

$0.11^{* * *}$

$0.39 * * *$

$0.27 * * *$

1.00

$0.18 * * *$

$-0.3 * * *$

$-0.09 * * *$

$0.44 * * *$

$0.10 * * * \quad 0.21 * * * \quad 0.16 * * *$

$0.29 * * * \quad 0.27 * *$

$0.29 * * *$

1.00

$0.13 * * *$

$-0.26 * * *$

$-0.11 * * * \quad 0.01$

(1)

$0.19 * * *$

$0.35 * * * \quad 0.07 * * * \quad 0.18 * * *$

1.00 
Table 4. Descriptive statistics of the variables

\begin{tabular}{|c|c|c|c|c|c|}
\hline VARIABLES & observations & mean & $\begin{array}{l}\text { standard } \\
\text { deviation }\end{array}$ & minimum & maximum \\
\hline $\begin{array}{l}\text { total portfolio invesment } \\
\text { assets to GDP ratio }\end{array}$ & 11518 & 91.2283 & 1461.203 & $-17.0498^{14}$ & 57077.25 \\
\hline $\begin{array}{l}\text { equity securities to GDP } \\
\text { ratio }\end{array}$ & 9952 & 50.7719 & 701.4271 & -15.5254 & 27500.21 \\
\hline $\begin{array}{l}\text { debt securities to GDP } \\
\text { ratio }\end{array}$ & 10333 & 52.5141 & 889.874 & -20.8665 & 30981.24 \\
\hline short-term interest rate & 1121 & 4.8136 & 5.6887 & 0.052 & 78.4025 \\
\hline long-term interest rate & 7305 & 4.4135 & 1.5011 & 0.9933 & 11.7258 \\
\hline stock index & 11019 & 7289.211 & 11157.06 & 80.4475 & 67276.9 \\
\hline growth of stock index & 10966 & 0.0216 & 0.0473 & -0.1710 & 0.3778 \\
\hline unemployment rate & 12121 & 8.3552 & 7.0025 & 1.05 & 60.6020 \\
\hline CPI growth & 12983 & 0.0041 & 0.0074 & -0.0488 & -0.1409 \\
\hline $\begin{array}{l}\text { real effective exchange } \\
\text { rate }\end{array}$ & 12983 & 101.732 & 12.5261 & 70.6908 & 230.785 \\
\hline GDP growth & 12983 & 0.0310 & 0.0404 & -0.1981 & 0.1920 \\
\hline $\begin{array}{l}\text { current account to GDP } \\
\text { ratio }\end{array}$ & 12983 & 0.0055 & 0.0726 & -0.3024 & 0.2733 \\
\hline $\begin{array}{l}\text { government debt to GDP } \\
\text { ratio }\end{array}$ & 9347 & 0.4370 & 0.6587 & -1.7358 & 3.7903 \\
\hline $\begin{array}{l}\text { SD of short-term interest } \\
\text { rate }\end{array}$ & 11170 & 0.6271 & 1.3126 & 0.0000 & 21.0825 \\
\hline $\begin{array}{l}\text { SD of long-term interest } \\
\text { rate }\end{array}$ & 7305 & 0.3043 & 0.2109 & 0.0620 & 2.1571 \\
\hline $\begin{array}{l}\text { SD of stock index } \\
\text { growth }\end{array}$ & 10993 & 0.0573 & 0.0272 & 0.0148 & 0.1870 \\
\hline SD of stock index & 11019 & 801.4661 & 1496.825 & 3.2795 & 12106.44 \\
\hline $\begin{array}{l}\text { SD of unemployment } \\
\text { rate }\end{array}$ & 12121 & 0.3789 & 0.4082 & 0.0000 & 3.3422 \\
\hline SD of CPI growth & 12983 & 0.0047 & 0.0058 & 0.0000 & 0.4587 \\
\hline
\end{tabular}

\footnotetext{
${ }^{14}$ Some countries report their international portfolio investment position net of short position, so the negative sign of assets implies that the country sold more securities than it bought from the counterparty.
} 
Table 5. Portfolio investments, 2001-10

\begin{tabular}{|c|c|c|c|c|c|c|}
\hline \multirow[b]{2}{*}{ VARIABLES } & \multicolumn{3}{|c|}{ high concentration } & \multicolumn{3}{|c|}{ Interaction term } \\
\hline & $\begin{array}{l}\text { total } \\
(1)\end{array}$ & $\begin{array}{c}\text { equity } \\
(2)\end{array}$ & $\begin{array}{l}\text { debt } \\
(3)\end{array}$ & $\begin{array}{l}\text { total } \\
(4)\end{array}$ & $\begin{array}{c}\text { equity } \\
(5)\end{array}$ & $\begin{array}{l}\text { debt } \\
(6)\end{array}$ \\
\hline portfoli investment & $\begin{array}{c}0.908^{* * *} \\
(0.015)\end{array}$ & $\begin{array}{c}0.916 * * * \\
(0.016)\end{array}$ & $\begin{array}{c}0.924 * * * \\
(0.017)\end{array}$ & - & - & - \\
\hline short-term interest rate & $\begin{array}{l}-0.075 \\
(0.060)\end{array}$ & $\begin{array}{l}-0.099 \\
(0.077)\end{array}$ & $\begin{array}{l}-0.025 \\
(0.035)\end{array}$ & $\begin{array}{c}0.050 \\
(0.069)\end{array}$ & $\begin{array}{c}0.046 \\
(0.086)\end{array}$ & $\begin{array}{l}-0.022 \\
(0.046)\end{array}$ \\
\hline long-term interest rate & $\begin{array}{c}0.123 \\
(0.086)\end{array}$ & $\begin{array}{c}0.111 \\
(0.099)\end{array}$ & $\begin{array}{c}0.063 \\
(0.061)\end{array}$ & $\begin{array}{l}-0.122 \\
(0.093)\end{array}$ & $\begin{array}{l}-0.095 \\
(0.110)\end{array}$ & $\begin{array}{l}-0.020 \\
(0.070)\end{array}$ \\
\hline stock index & $\begin{array}{l}-0.000^{*} \\
(0.000)\end{array}$ & $\begin{array}{c}0.000 \\
(0.000)\end{array}$ & $\begin{array}{c}-0.000 * * * \\
(0.000)\end{array}$ & $\begin{array}{c}0.000 \\
(0.000)\end{array}$ & $\begin{array}{l}-0.000 \\
(0.000)\end{array}$ & $\begin{array}{l}0.000^{*} \\
(0.000)\end{array}$ \\
\hline growth of stock index & $\begin{array}{c}2.890 \\
(2.211)\end{array}$ & $\begin{array}{c}9.493 * * * \\
(3.238)\end{array}$ & $\begin{array}{c}1.718 \\
(2.105)\end{array}$ & $\begin{array}{l}-2.693 \\
(2.308)\end{array}$ & $\begin{array}{c}-0.143 \\
(3.371)\end{array}$ & $\begin{array}{l}-4.047 * \\
(2.124)\end{array}$ \\
\hline unemployment rate & $\begin{array}{l}-0.006 \\
(0.013)\end{array}$ & $\begin{array}{l}-0.018 \\
(0.013)\end{array}$ & $\begin{array}{l}-0.007 \\
(0.014)\end{array}$ & $\begin{array}{c}0.011 \\
(0.015)\end{array}$ & $\begin{array}{c}0.019 \\
(0.017)\end{array}$ & $\begin{array}{c}0.015 \\
(0.017)\end{array}$ \\
\hline inflation & $\begin{array}{l}-22.37^{*} \\
(12.04)\end{array}$ & $\begin{array}{l}-38.08^{*} \\
(19.82)\end{array}$ & $\begin{array}{l}-7.976 \\
(10.93)\end{array}$ & $\begin{array}{c}36.06^{* *} \\
(14.01)\end{array}$ & $\begin{array}{c}58.22 * * * \\
(21.48)\end{array}$ & $\begin{array}{c}10.39 \\
(12.56)\end{array}$ \\
\hline real effective exchange rate & $\begin{array}{l}-0.003 \\
(0.003)\end{array}$ & $\begin{array}{c}-0.002 \\
(0.003)\end{array}$ & $\begin{array}{c}-0.005 \\
(0.003)\end{array}$ & $\begin{array}{c}0.003 \\
(0.002)\end{array}$ & $\begin{array}{c}0.005^{* *} \\
(0.003)\end{array}$ & $\begin{array}{l}-0.001 \\
(0.002)\end{array}$ \\
\hline GDP growth & $\begin{array}{l}-3.786^{*} \\
(1.882)\end{array}$ & $\begin{array}{c}-0188 \\
(1.922)\end{array}$ & $\begin{array}{c}-5.298 * * * \\
(1.880)\end{array}$ & $\begin{array}{c}3.425 \\
(2.201)\end{array}$ & $\begin{array}{l}-1.307 \\
(2.366)\end{array}$ & $\begin{array}{c}4.509 * * * * \\
(1.947)\end{array}$ \\
\hline $\begin{array}{l}\text { current account to GDP } \\
\text { ratio }\end{array}$ & $\begin{array}{l}-0.395 \\
(0.615)\end{array}$ & $\begin{array}{l}-0.012 \\
(0.768)\end{array}$ & $\begin{array}{l}-0.540 \\
(0.683)\end{array}$ & $\begin{array}{c}0.779 \\
(0.773)\end{array}$ & $\begin{array}{c}0.064 \\
(0.879)\end{array}$ & $\begin{array}{c}0.794 \\
(0.947)\end{array}$ \\
\hline $\begin{array}{l}\text { government debt to GDP } \\
\text { ratio }\end{array}$ & $\begin{array}{l}-0.094 \\
(0.083)\end{array}$ & $\begin{array}{l}-0.073 \\
(0.082)\end{array}$ & $\begin{array}{l}-0.064 \\
(0.091)\end{array}$ & $\begin{array}{c}0.171 \\
(0.116)\end{array}$ & $\begin{array}{l}0.048 \\
(0.101)\end{array}$ & $\begin{array}{l}0.067 \\
(0.120)\end{array}$ \\
\hline $\begin{array}{l}\text { SD of short-term interest } \\
\text { rate }\end{array}$ & $\begin{array}{l}-0.154 \\
(0.209)\end{array}$ & $\begin{array}{c}0.003 \\
(0.281)\end{array}$ & $\begin{array}{l}-0.055 \\
(0.222)\end{array}$ & $\begin{array}{c}0.402 \\
(0.265)\end{array}$ & $\begin{array}{c}-0.012 \\
(0.344)\end{array}$ & $\begin{array}{c}0.166 \\
(0.266)\end{array}$ \\
\hline $\begin{array}{l}\text { SD of long-term interest } \\
\text { rate }\end{array}$ & $\begin{array}{l}-0.127 \\
(0.231)\end{array}$ & $\begin{array}{c}0.007 \\
(0.293)\end{array}$ & $\begin{array}{l}-0.443^{*} \\
(0.258)\end{array}$ & $\begin{array}{l}0.107 \\
(0.275)\end{array}$ & $\begin{array}{l}0.067 \\
(0.349)\end{array}$ & $\begin{array}{c}0.497 * * * \\
(0.305)\end{array}$ \\
\hline SD of stock index growth & $\begin{array}{l}1.271 \\
(2.016)\end{array}$ & $\begin{array}{l}1.422 \\
(2.405)\end{array}$ & $\begin{array}{l}1.362 \\
(1.964)\end{array}$ & $\begin{array}{c}0.763 \\
(2.607)\end{array}$ & $\begin{array}{l}-3.275 \\
(3.170)\end{array}$ & $\begin{array}{c}0.130 \\
(2.447)\end{array}$ \\
\hline SD of stock index & $\begin{array}{c}0.000 \\
(0.000)\end{array}$ & $\begin{array}{l}-0.000 \\
(0.000)\end{array}$ & $\begin{array}{l}0.000 \\
(0.000)\end{array}$ & $\begin{array}{l}-0.000 \\
(0.000)\end{array}$ & $\begin{array}{l}0.000 \\
(0.000)\end{array}$ & $\begin{array}{l}-0.000 \\
(0.000)\end{array}$ \\
\hline SD of unemployment rate & $\begin{array}{l}-0.019 \\
(0.133)\end{array}$ & $\begin{array}{l}-0.069 \\
(0.145)\end{array}$ & $\begin{array}{l}0.096 \\
(0.122)\end{array}$ & $\begin{array}{c}0.081 \\
(0.187)\end{array}$ & $\begin{array}{c}0.218 \\
(0.198)\end{array}$ & $\begin{array}{l}-0.165 \\
(0.159)\end{array}$ \\
\hline SD of inflation & $\begin{array}{l}-5.234 \\
(27.37) \\
\end{array}$ & $\begin{array}{l}82.91 * * \\
(35.61)\end{array}$ & $\begin{array}{l}-36.82 \\
(25.99) \\
\end{array}$ & $\begin{array}{l}-45.87 \\
(32.86) \\
\end{array}$ & $\begin{array}{c}-84.46^{* *} \\
(41.48) \\
\end{array}$ & $\begin{array}{r}7.809 \\
(28.79) \\
\end{array}$ \\
\hline $\mathrm{N}$ observations & 3,078 & 2,774 & 2,885 & & & \\
\hline $\mathrm{N}$ country-country id & 537 & 511 & 518 & & & \\
\hline $\mathrm{N}$ instruments & 521 & 521 & 521 & & & \\
\hline AR (1) p-value & 0.00 & 0.00 & 0.000 & & & \\
\hline AR (2) p-value & 0.75 & 0.73 & 0.62 & & & \\
\hline Hansen p-value & 0.80 & 0.94 & 0.95 & & & \\
\hline
\end{tabular}

Robust standard errors are in parentheses

$$
* * * \mathrm{p}<0.01, * * \mathrm{p}<0.05, * \mathrm{p}<0.1
$$


Table 6. Portfolio investments, 2001-10, share below or equal to 1 percent

\begin{tabular}{|c|c|c|c|c|c|c|}
\hline \multirow[b]{2}{*}{ VARIABLES } & \multicolumn{3}{|c|}{ high concentration } & \multicolumn{3}{|c|}{ Interaction term } \\
\hline & $\begin{array}{l}\text { total } \\
(1)\end{array}$ & $\begin{array}{l}\text { equity } \\
\text { (2) }\end{array}$ & $\begin{array}{l}\text { debt } \\
(3)\end{array}$ & $\begin{array}{c}\text { total } \\
(4)\end{array}$ & $\begin{array}{l}\text { equity } \\
\text { (5) }\end{array}$ & $\begin{array}{c}\text { debt } \\
(6)\end{array}$ \\
\hline portfoli investment & $\begin{array}{c}0.880^{* *} \\
(0.018)\end{array}$ & $\begin{array}{c}0.892^{* *} \\
(0.019)\end{array}$ & $\begin{array}{c}0.895 * * * \\
(0.019)\end{array}$ & - & - & - \\
\hline short-term interest rate & $\begin{array}{l}-0.090 \\
(0.082)\end{array}$ & $\begin{array}{c}-0.073 \\
(0.117)\end{array}$ & $\begin{array}{c}0.020 \\
(0.051)\end{array}$ & $\begin{array}{c}0.051 \\
(0.097)\end{array}$ & $\begin{array}{c}0.057 \\
(0.142)\end{array}$ & $\begin{array}{c}0.107 \\
(0.069)\end{array}$ \\
\hline long-term interest rate & $\begin{array}{c}0.180 \\
(0.112)\end{array}$ & $\begin{array}{c}0.109 \\
(0.148)\end{array}$ & $\begin{array}{c}0.041 \\
(0.075)\end{array}$ & $\begin{array}{l}-0.106 \\
(0.134)\end{array}$ & $\begin{array}{l}-0.121 \\
(0.178)\end{array}$ & $\begin{array}{c}0.154 \\
(0.100)\end{array}$ \\
\hline stock index & $\begin{array}{l}-0.000 \\
(0.000)\end{array}$ & $\begin{array}{c}0.000 \\
(0.000)\end{array}$ & $\begin{array}{c}-0.000 * * * \\
(0.000)\end{array}$ & $\begin{array}{c}0.000 \\
(0.000)\end{array}$ & $\begin{array}{l}-0.000 \\
(0.000)\end{array}$ & $\begin{array}{l}0.000^{* *} \\
(0.000)\end{array}$ \\
\hline growth of stock index & $\begin{array}{c}3.415 \\
(3.430)\end{array}$ & $\begin{array}{l}10.29 * * \\
(5.248)\end{array}$ & $\begin{array}{c}4.834 \\
(3.681)\end{array}$ & $\begin{array}{c}0.815 \\
(3.851)\end{array}$ & $\begin{array}{c}6.408 \\
(5.782)\end{array}$ & $\begin{array}{l}-4.913 \\
(3.305)\end{array}$ \\
\hline unemployment rate & $\begin{array}{c}0.000 \\
(0.018)\end{array}$ & $\begin{array}{l}-0.006 \\
(0.019)\end{array}$ & $\begin{array}{c}0.004 \\
(0.019)\end{array}$ & $\begin{array}{l}-0.002 \\
(0.022)\end{array}$ & $\begin{array}{c}0.005 \\
(0.027)\end{array}$ & $\begin{array}{l}-0.011 \\
(0.024)\end{array}$ \\
\hline inflation & $\begin{array}{l}-13.28 \\
(18.50)\end{array}$ & $\begin{array}{l}0.745 \\
(26.74)\end{array}$ & $\begin{array}{l}2.981 \\
(19.30)\end{array}$ & $\begin{array}{l}25.21 \\
(18.64)\end{array}$ & $\begin{array}{l}21.40 \\
(29.43)\end{array}$ & $\begin{array}{l}-5.906 \\
(19.69)\end{array}$ \\
\hline real effective exchange rate & $\begin{array}{l}-0.002 \\
(0.004)\end{array}$ & $\begin{array}{l}-0.001 \\
(0.004)\end{array}$ & $\begin{array}{l}-0.002 \\
(0.006)\end{array}$ & $\begin{array}{c}0.002 \\
(0.003)\end{array}$ & $\begin{array}{c}0.005 \\
(0.004)\end{array}$ & $\begin{array}{l}-0.003 \\
(0.003)\end{array}$ \\
\hline GDP growth & $\begin{array}{l}-1.261 \\
(2.375)\end{array}$ & $\begin{array}{c}0.371 \\
(2.820)\end{array}$ & $\begin{array}{l}-1.234 \\
(2.631)\end{array}$ & $\begin{array}{l}1.830 \\
(2.615)\end{array}$ & $\begin{array}{l}2.373 \\
(3.769)\end{array}$ & $\begin{array}{l}-0.191 \\
(2.656)\end{array}$ \\
\hline $\begin{array}{l}\text { current account to GDP } \\
\text { ratio }\end{array}$ & $\begin{array}{c}0.469 \\
(0.835)\end{array}$ & $\begin{array}{l}1.103 \\
(1.125)\end{array}$ & $\begin{array}{l}1.376 \\
(1.018)\end{array}$ & $\begin{array}{c}0.154 \\
(1.036)\end{array}$ & $\begin{array}{l}-0.789 \\
(1.275)\end{array}$ & $\begin{array}{l}-1.237 \\
(1.373)\end{array}$ \\
\hline $\begin{array}{l}\text { government debt to GDP } \\
\text { ratio }\end{array}$ & $\begin{array}{l}-0.061 \\
(0.085)\end{array}$ & $\begin{array}{l}-0.047 \\
(0.116)\end{array}$ & $\begin{array}{c}0.029 \\
(0.104)\end{array}$ & $\begin{array}{c}0.002 \\
(0.111)\end{array}$ & $\begin{array}{l}-0.012 \\
(0.143)\end{array}$ & $\begin{array}{l}-0.186 \\
(0.142)\end{array}$ \\
\hline $\begin{array}{l}\text { SD of short-term interest } \\
\text { rate }\end{array}$ & $\begin{array}{c}0.017 \\
(0.290)\end{array}$ & $\begin{array}{l}-0.109 \\
(0.348)\end{array}$ & $\begin{array}{c}0.089 \\
(0.350)\end{array}$ & $\begin{array}{c}0.247 \\
(0.337)\end{array}$ & $\begin{array}{c}0.233 \\
(0.428)\end{array}$ & $\begin{array}{l}-0.011 \\
(0.431)\end{array}$ \\
\hline $\begin{array}{l}\text { SD of long-term interest } \\
\text { rate }\end{array}$ & $\begin{array}{c}-0.781 * * \\
(0.368)\end{array}$ & $\begin{array}{l}-0.099 \\
(0.654)\end{array}$ & $\begin{array}{c}-1.221 * * * \\
(0.443)\end{array}$ & $\begin{array}{l}0.910^{*} \\
(0.476)\end{array}$ & $\begin{array}{c}0.187 \\
(0.806)\end{array}$ & $\begin{array}{c}1.548 * * * \\
(0.522)\end{array}$ \\
\hline SD of stock index growth & $\begin{array}{c}1.679 \\
(3.128)\end{array}$ & $\begin{array}{l}-0.038 \\
(4.017)\end{array}$ & $\begin{array}{c}1.906 \\
(3.819)\end{array}$ & $\begin{array}{c}3.357 \\
(4.115)\end{array}$ & $\begin{array}{c}0.282 \\
(5.665)\end{array}$ & $\begin{array}{c}1.225 \\
(4.719)\end{array}$ \\
\hline SD of stock index & $\begin{array}{l}0.000 \\
(0.000)\end{array}$ & $\begin{array}{l}-0.000^{*} \\
(0.000)\end{array}$ & $\begin{array}{c}0.000 \\
(0.000)\end{array}$ & $\begin{array}{l}-0.000 \\
(0.000)\end{array}$ & $\begin{array}{c}0.000 \\
(0.000)\end{array}$ & $\begin{array}{l}-0.000^{*} \\
(0.000)\end{array}$ \\
\hline SD of unemployment rate & $\begin{array}{l}-0.144 \\
(0.152)\end{array}$ & $\begin{array}{l}-0.193 \\
(0.174)\end{array}$ & $\begin{array}{c}0.034 \\
(0.172)\end{array}$ & $\begin{array}{c}0.075 \\
(0.193)\end{array}$ & $\begin{array}{c}0.232 \\
(0.246)\end{array}$ & $\begin{array}{l}-0.172 \\
(0.220)\end{array}$ \\
\hline SD of inflation & $\begin{array}{c}30.88 \\
(33.11) \\
\end{array}$ & $\begin{array}{c}108.00^{* *} \\
(46.56)\end{array}$ & $\begin{array}{l}-0.873 \\
(33.62) \\
\end{array}$ & $\begin{array}{c}-87.38 * * \\
(39.18) \\
\end{array}$ & $\begin{array}{c}-103.1 * * \\
(51.26)\end{array}$ & $\begin{array}{l}-19.88 \\
(35.65) \\
\end{array}$ \\
\hline $\mathrm{N}$ observations & 1,447 & 1,213 & 1,276 & & & \\
\hline $\mathrm{N}$ country-country id & 323 & 287 & 301 & & & \\
\hline $\mathrm{N}$ instruments & 478 & 473 & 475 & & & \\
\hline $\operatorname{AR}(1) p$-value & 0.00 & 0.00 & 0.00 & & & \\
\hline AR (2) p-value & 0.99 & 0.15 & 0.69 & & & \\
\hline Hansen p-value & 1.00 & 1.00 & 1.00 & & & \\
\hline
\end{tabular}

Robust standard errors are in parentheses

$$
* * * \mathrm{p}<0.01, * * \mathrm{p}<0.05, * \mathrm{p}<0.1
$$


Table 7. Portfolio investments, 2001-10, share in the range of 1 and 7 percent

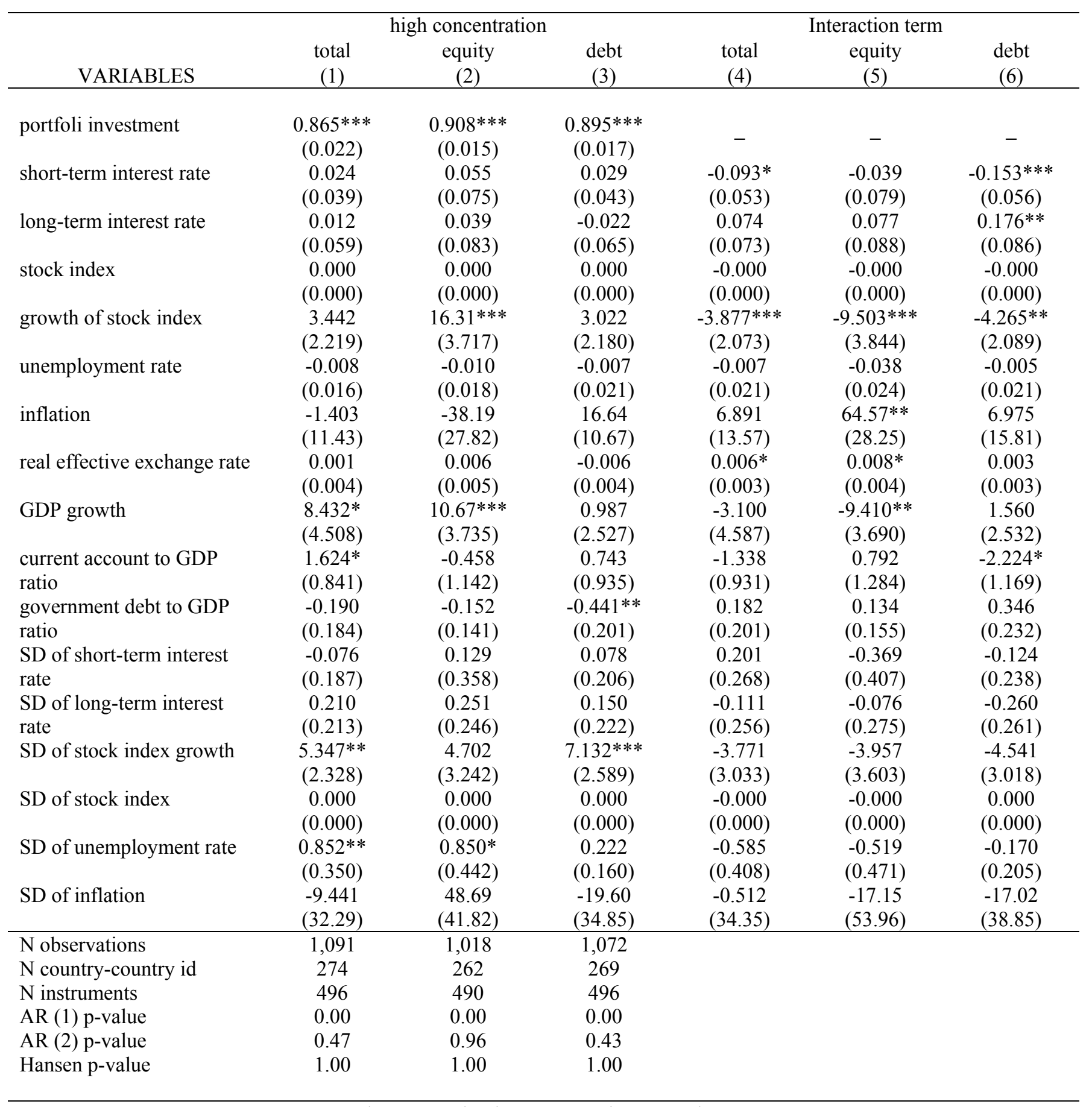

Robust standard errors are in parentheses

$$
* * * \mathrm{p}<0.01, * * \mathrm{p}<0.05, * \mathrm{p}<0.1
$$


Table 8. Portfolio investments, 2001-10, share equal to or above 7 percent

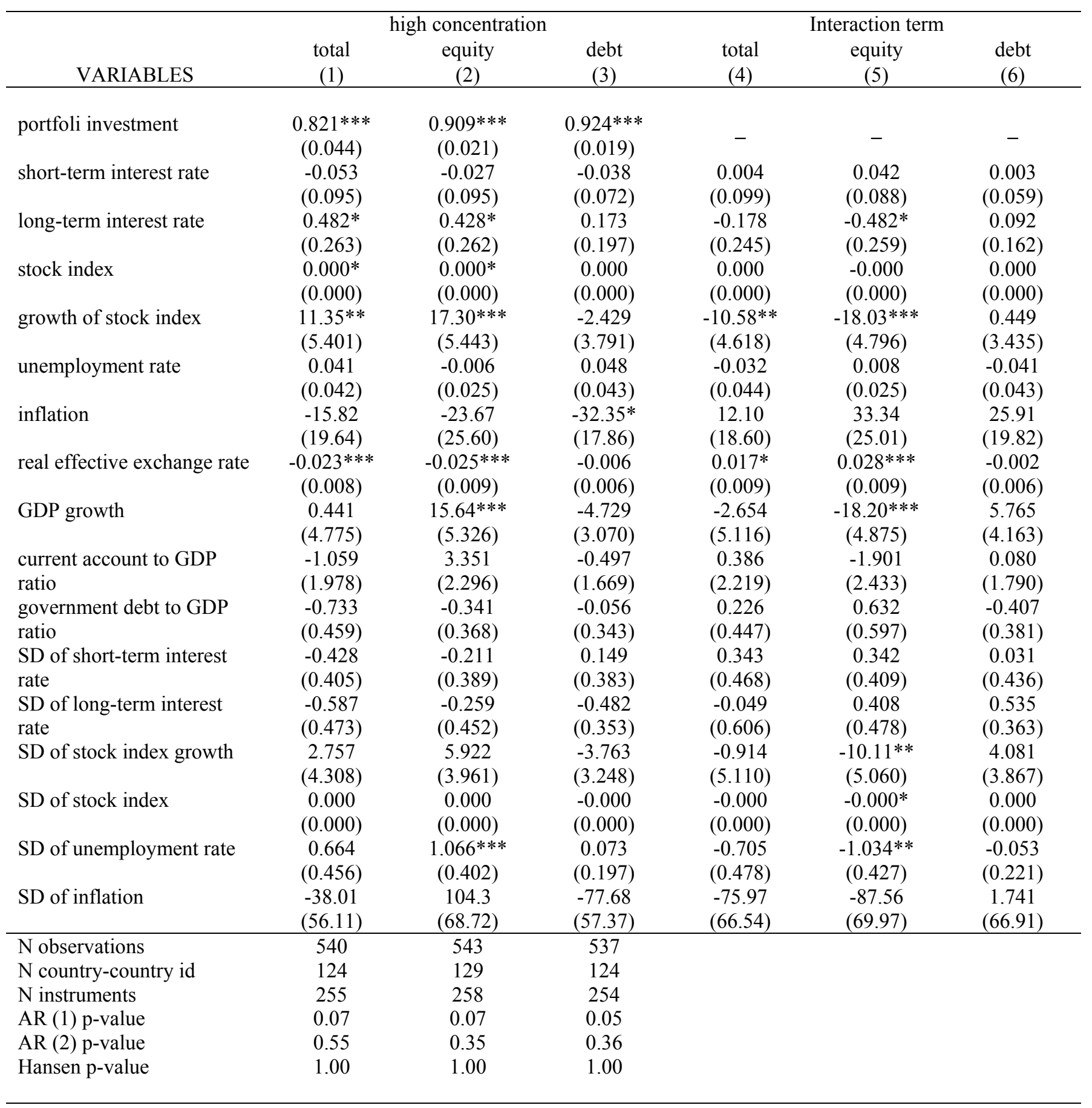

Robust standard errors are in parentheses

$$
* * * \mathrm{p}<0.01, * * \mathrm{p}<0.05, * \mathrm{p}<0.1
$$


Table 9. Portfolio investments, 2001-06

\begin{tabular}{|c|c|c|c|c|c|c|}
\hline \multirow[b]{2}{*}{ VARIABLES } & \multicolumn{3}{|c|}{ high concentration } & \multicolumn{3}{|c|}{ Interaction term } \\
\hline & $\begin{array}{l}\text { total } \\
(1)\end{array}$ & $\begin{array}{c}\text { equity } \\
\text { (2) }\end{array}$ & $\begin{array}{l}\text { debt } \\
(3)\end{array}$ & $\begin{array}{l}\text { total } \\
(4)\end{array}$ & $\begin{array}{c}\text { equity } \\
(5)\end{array}$ & $\begin{array}{l}\text { debt } \\
(6)\end{array}$ \\
\hline portfoli investment & $\begin{array}{c}0.880 * * * \\
(0.026)\end{array}$ & $\begin{array}{c}0.891 * * * \\
(0.021)\end{array}$ & $\begin{array}{c}0.910^{* * *} \\
(0.029)\end{array}$ & - & - & - \\
\hline short-term interest rate & $\begin{array}{c}0.112 \\
(0.071)\end{array}$ & $\begin{array}{c}0.048 \\
(0.095)\end{array}$ & $\begin{array}{c}0.031 \\
(0.054)\end{array}$ & $\begin{array}{l}-0.138^{*} \\
(0.080)\end{array}$ & $\begin{array}{l}-0.106 \\
(0.111)\end{array}$ & $\begin{array}{c}-0.032 \\
(0.073)\end{array}$ \\
\hline long-term interest rate & $\begin{array}{c}-0.040 \\
(0.090)\end{array}$ & $\begin{array}{l}-0.074 \\
(0.111)\end{array}$ & $\begin{array}{c}0.014 \\
(0.076)\end{array}$ & $\begin{array}{c}0.022 \\
(0.095)\end{array}$ & $\begin{array}{c}0.087 \\
(0.126)\end{array}$ & $\begin{array}{l}-0.009 \\
(0.089)\end{array}$ \\
\hline stock index & $\begin{array}{c}0.000 \\
(0.000)\end{array}$ & $\begin{array}{l}0.000 \\
(0.000)\end{array}$ & $\begin{array}{c}0.000 \\
(0.000)\end{array}$ & $\begin{array}{l}-0.000 \\
(0.000)\end{array}$ & $\begin{array}{l}-0.000 \\
(0.000)\end{array}$ & $\begin{array}{c}0.000 \\
(0.000)\end{array}$ \\
\hline growth of stock index & $\begin{array}{c}6.326^{* *} \\
(3.212)\end{array}$ & $\begin{array}{c}15.95 * * * \\
(3.936)\end{array}$ & $\begin{array}{c}4.627 \\
(3.042)\end{array}$ & $\begin{array}{l}-5.125 \\
(3.747)\end{array}$ & $\begin{array}{l}-3.026 \\
(4.961)\end{array}$ & $\begin{array}{c}-5.688 \\
(3.710)\end{array}$ \\
\hline unemployment rate & $\begin{array}{l}-0.008 \\
(0.024)\end{array}$ & $\begin{array}{l}-0.040 \\
(0.028)\end{array}$ & $\begin{array}{l}-0.006 \\
(0.022)\end{array}$ & $\begin{array}{c}0.025 \\
(0.032)\end{array}$ & $\begin{array}{c}0.048 \\
(0.035)\end{array}$ & $\begin{array}{c}0.022 \\
(0.031)\end{array}$ \\
\hline inflation & $\begin{array}{l}-10.75 \\
(33.55)\end{array}$ & $\begin{array}{l}-24.30 \\
(45.89)\end{array}$ & $\begin{array}{l}15.38 \\
(23.11)\end{array}$ & $\begin{array}{c}51.26 \\
(42.79)\end{array}$ & $\begin{array}{l}67.86 \\
(57.55)\end{array}$ & $\begin{array}{l}-1.417 \\
(27.02)\end{array}$ \\
\hline real effective exchange rate & $\begin{array}{l}-0.006 \\
(0.005)\end{array}$ & $\begin{array}{l}-0.009 \\
(0.007)\end{array}$ & $\begin{array}{l}-0.002 \\
(0.007)\end{array}$ & $\begin{array}{c}0.008 * * \\
(0.003)\end{array}$ & $\begin{array}{c}0.005 \\
(0.004)\end{array}$ & $\begin{array}{c}0.001 \\
(0.003)\end{array}$ \\
\hline GDP growth & $\begin{array}{c}2.918 \\
(4.406)\end{array}$ & $\begin{array}{l}-0.067 \\
(3.973)\end{array}$ & $\begin{array}{c}0.863 \\
(4.462)\end{array}$ & $\begin{array}{l}-4.008 \\
(5.192)\end{array}$ & $\begin{array}{l}-2.633 \\
(4.811)\end{array}$ & $\begin{array}{c}-1.894 \\
(5.249)\end{array}$ \\
\hline $\begin{array}{l}\text { current account to GDP } \\
\text { ratio }\end{array}$ & $\begin{array}{c}2.497 * * \\
(1.028)\end{array}$ & $\begin{array}{l}1.027 \\
(1.362)\end{array}$ & $\begin{array}{c}0.492 \\
(1.135)\end{array}$ & $\begin{array}{l}-2.063^{*} \\
(1.266)\end{array}$ & $\begin{array}{l}-0.859 \\
(1.435)\end{array}$ & $\begin{array}{l}-0.111 \\
(1.546)\end{array}$ \\
\hline $\begin{array}{l}\text { government debt to GDP } \\
\text { ratio }\end{array}$ & $\begin{array}{c}0.144 \\
(0.101)\end{array}$ & $\begin{array}{c}0.128 \\
(0.111)\end{array}$ & $\begin{array}{c}0.020 \\
(0.128)\end{array}$ & $\begin{array}{l}-0.059 \\
(0.130)\end{array}$ & $\begin{array}{l}-0.125 \\
(0.130)\end{array}$ & $\begin{array}{c}0.009 \\
(0.164)\end{array}$ \\
\hline $\begin{array}{l}\mathrm{SD} \text { of short-term interest } \\
\text { rate }\end{array}$ & $\begin{array}{c}-0.887 * * \\
(0.446)\end{array}$ & $\begin{array}{l}-0.573 \\
(0.525)\end{array}$ & $\begin{array}{l}-0.293 \\
(0.367)\end{array}$ & $\begin{array}{c}1.474 * * * \\
(0.554)\end{array}$ & $\begin{array}{c}0.786 \\
(0.661)\end{array}$ & $\begin{array}{c}0.453 \\
(0.443)\end{array}$ \\
\hline $\begin{array}{l}\text { SD of long-term interest } \\
\text { rate }\end{array}$ & $\begin{array}{c}1.070 \\
(0.826)\end{array}$ & $\begin{array}{c}0.738 \\
(1.060)\end{array}$ & $\begin{array}{l}-0.016 \\
(0.716)\end{array}$ & $\begin{array}{l}-0.744 \\
(0.946)\end{array}$ & $\begin{array}{l}-0.581 \\
(1.167)\end{array}$ & $\begin{array}{c}0.970 \\
(0.805)\end{array}$ \\
\hline SD of stock index growth & $\begin{array}{c}4.593 \\
(3.326)\end{array}$ & $\begin{array}{c}5.845 \\
(4.342)\end{array}$ & $\begin{array}{c}4.064 \\
(2.799)\end{array}$ & $\begin{array}{l}-3.634 \\
(3.657)\end{array}$ & $\begin{array}{l}-6.608 \\
(5.504)\end{array}$ & $\begin{array}{l}-1.471 \\
(3.168)\end{array}$ \\
\hline SD of stock index & $\begin{array}{l}-0.000 \\
(0.000)\end{array}$ & $\begin{array}{l}-0.000 \\
(0.000)\end{array}$ & $\begin{array}{l}-0.000 \\
(0.000)\end{array}$ & $\begin{array}{c}0.000 \\
(0.000)\end{array}$ & $\begin{array}{c}0.000 \\
(0.000)\end{array}$ & $\begin{array}{l}-0.000 \\
(0.000)\end{array}$ \\
\hline SD of unemployment rate & $\begin{array}{l}-0.093 \\
(0.340)\end{array}$ & $\begin{array}{c}0.306 \\
(0.423)\end{array}$ & $\begin{array}{l}-0.042 \\
(0.260)\end{array}$ & $\begin{array}{l}-0.130 \\
(0.445)\end{array}$ & $\begin{array}{l}-0.357 \\
(0.514)\end{array}$ & $\begin{array}{l}-0.296 \\
(0.359)\end{array}$ \\
\hline SD of inflation & $\begin{array}{c}15.33 \\
(43.84) \\
\end{array}$ & $\begin{array}{l}131.8^{*} \\
(67.28)\end{array}$ & $\begin{array}{l}-57.68 \\
(42.50) \\
\end{array}$ & $\begin{array}{l}-100.7^{*} \\
(55.09)\end{array}$ & $\begin{array}{l}-152.5^{*} \\
(80.54) \\
\end{array}$ & $\begin{array}{c}13.91 \\
(45.60) \\
\end{array}$ \\
\hline $\mathrm{N}$ observations & 1,547 & 1,384 & 1,448 & & & \\
\hline $\mathrm{N}$ country-country id & 495 & 457 & 467 & & & \\
\hline $\mathrm{N}$ instruments & 322 & 320 & 322 & & & \\
\hline AR (1) p-value & 0.00 & 0.00 & 0.00 & & & \\
\hline AR (2) p-value & 0.44 & 0.24 & 0.10 & & & \\
\hline Hansen p-value & 0.40 & 0.58 & 0.23 & & & \\
\hline
\end{tabular}

Robust standard errors are in parentheses $* * * \mathrm{p}<0.01, * * \mathrm{p}<0.05, * \mathrm{p}<0.1$ 
Table 10. Portfolio investments, 2001-06, share below or equal to 1 percent

\begin{tabular}{|c|c|c|c|c|c|c|}
\hline \multirow[b]{2}{*}{ VARIABLES } & \multicolumn{3}{|c|}{ high concentration } & \multicolumn{3}{|c|}{ Interaction term } \\
\hline & $\begin{array}{l}\text { total } \\
\text { (1) }\end{array}$ & $\begin{array}{c}\text { equity } \\
\text { (2) }\end{array}$ & $\begin{array}{c}\text { debt } \\
\text { (3) }\end{array}$ & $\begin{array}{l}\text { total } \\
(4)\end{array}$ & $\begin{array}{l}\text { equity } \\
\text { (5) }\end{array}$ & $\begin{array}{c}\text { debt } \\
(6)\end{array}$ \\
\hline portfoli investment & $\begin{array}{c}0.870 * * * \\
(0.027)\end{array}$ & $\begin{array}{c}0.892 * * * \\
(0.022)\end{array}$ & $\begin{array}{c}0.894 * * * \\
(0.029)\end{array}$ & - & - & - \\
\hline short-term interest rate & $\begin{array}{c}0.121 \\
(0.110)\end{array}$ & $\begin{array}{c}0.172 \\
(0.161)\end{array}$ & $\begin{array}{c}0.083 \\
(0.093)\end{array}$ & $\begin{array}{c}-0.213 \\
(0.135)\end{array}$ & $\begin{array}{c}-0.230 \\
(0.199)\end{array}$ & $\begin{array}{c}-0.136 \\
(0.141)\end{array}$ \\
\hline long-term interest rate & $\begin{array}{c}0.023 \\
(0.119)\end{array}$ & $\begin{array}{l}-0.103 \\
(0.179)\end{array}$ & $\begin{array}{c}0.055 \\
(0.105)\end{array}$ & $\begin{array}{c}0.099 \\
(0.154)\end{array}$ & $\begin{array}{c}0.130 \\
(0.230)\end{array}$ & $\begin{array}{c}0.073 \\
(0.158)\end{array}$ \\
\hline stock index & $\begin{array}{c}-0.000 \\
(0.000)\end{array}$ & $\begin{array}{l}-0.000 \\
(0.000)\end{array}$ & $\begin{array}{c}-0.000 \\
(0.000)\end{array}$ & $\begin{array}{c}0.000 \\
(0.000)\end{array}$ & $\begin{array}{c}0.000 \\
(0.000)\end{array}$ & $\begin{array}{c}0.000 \\
(0.000)\end{array}$ \\
\hline growth of stock index & $\begin{array}{l}10.95 * \\
(6.079)\end{array}$ & $\begin{array}{c}20.06^{* * *} * \\
(7.488)\end{array}$ & $\begin{array}{l}15.77 * * \\
(6.545)\end{array}$ & $\begin{array}{l}-6.520 \\
(7.145)\end{array}$ & $\begin{array}{c}6.118 \\
(9.399)\end{array}$ & $\begin{array}{c}-14.20^{*} \\
(6.565)\end{array}$ \\
\hline unemployment rate & $\begin{array}{c}0.026 \\
(0.038)\end{array}$ & $\begin{array}{l}-0.021 \\
(0.041)\end{array}$ & $\begin{array}{c}0.026 \\
(0.046)\end{array}$ & $\begin{array}{l}-0.042 \\
(0.049)\end{array}$ & $\begin{array}{c}0.042 \\
(0.050)\end{array}$ & $\begin{array}{c}-0.024 \\
(0.064)\end{array}$ \\
\hline inflation & $\begin{array}{c}7.201 \\
(45.54)\end{array}$ & $\begin{array}{l}79.69 * \\
(45.07)\end{array}$ & $\begin{array}{c}39.86 \\
(41.28)\end{array}$ & $\begin{array}{c}19.40 \\
(49.03)\end{array}$ & $\begin{array}{l}-60.25 \\
(60.34)\end{array}$ & $\begin{array}{l}-29.18 \\
(46.14)\end{array}$ \\
\hline real effective exchange rate & $\begin{array}{l}-0.009 \\
(0.009)\end{array}$ & $\begin{array}{l}-0.001 \\
(0.010)\end{array}$ & $\begin{array}{l}-0.003 \\
(0.012)\end{array}$ & $\begin{array}{c}0.007 \\
(0.005)\end{array}$ & $\begin{array}{c}0.004 \\
(0.005)\end{array}$ & $\begin{array}{c}0.002 \\
(0.005)\end{array}$ \\
\hline GDP growth & $\begin{array}{c}1.774 \\
(7.627)\end{array}$ & $\begin{array}{l}-1.499 \\
(7.081)\end{array}$ & $\begin{array}{c}-0.556 \\
(8.459)\end{array}$ & $\begin{array}{l}-4.806 \\
(9.419)\end{array}$ & $\begin{array}{l}-3.168 \\
(8.773)\end{array}$ & $\begin{array}{c}-6.578 \\
(10.73)\end{array}$ \\
\hline $\begin{array}{l}\text { current account to GDP } \\
\text { ratio }\end{array}$ & $\begin{array}{l}4.233 * * \\
(1.888)\end{array}$ & $\begin{array}{l}5.457 * * \\
(2.507)\end{array}$ & $\begin{array}{c}2.503 \\
(1.841)\end{array}$ & $\begin{array}{l}-4.237^{*} \\
(2.405)\end{array}$ & $\begin{array}{l}-6.425 * * \\
(2.979)\end{array}$ & $\begin{array}{l}-2.353 \\
(2.784)\end{array}$ \\
\hline $\begin{array}{l}\text { government debt to GDP } \\
\text { ratio }\end{array}$ & $\begin{array}{l}0.198 * \\
(0.122)\end{array}$ & $\begin{array}{c}0.228 \\
(0.172)\end{array}$ & $\begin{array}{c}0.106 \\
(0.144)\end{array}$ & $\begin{array}{l}-0.331^{*} \\
(0.181)\end{array}$ & $\begin{array}{l}-0.311 \\
(0.251)\end{array}$ & $\begin{array}{l}-0.260 \\
(0.223)\end{array}$ \\
\hline $\begin{array}{l}\text { SD of short-term interest } \\
\text { rate }\end{array}$ & $\begin{array}{l}-0.549 \\
(0.507)\end{array}$ & $\begin{array}{l}-0.602 \\
(0.454)\end{array}$ & $\begin{array}{l}-0.047 \\
(0.598)\end{array}$ & $\begin{array}{l}1.037 * \\
(0.612)\end{array}$ & $\begin{array}{l}1.176^{*} \\
(0.609)\end{array}$ & $\begin{array}{c}0.099 \\
(0.752)\end{array}$ \\
\hline $\begin{array}{l}\text { SD of long-term interest } \\
\text { rate }\end{array}$ & $\begin{array}{l}-1.177 \\
(1.248)\end{array}$ & $\begin{array}{c}0.114 \\
(1.339)\end{array}$ & $\begin{array}{l}-1.490 \\
(1.177)\end{array}$ & $\begin{array}{l}2.761^{*} \\
(1.593)\end{array}$ & $\begin{array}{c}0.481 \\
(1.573)\end{array}$ & $\begin{array}{l}3.707 * * * \\
(1.332)\end{array}$ \\
\hline SD of stock index growth & $\begin{array}{c}9.729 \\
(6.680)\end{array}$ & $\begin{array}{l}-3.255 \\
(9.295)\end{array}$ & $\begin{array}{c}7.831 \\
(5.662)\end{array}$ & $\begin{array}{l}-7.044 \\
(8.584)\end{array}$ & $\begin{array}{c}1.399 \\
(12.26)\end{array}$ & $\begin{array}{l}-3.171 \\
(7.909)\end{array}$ \\
\hline SD of stock index & $\begin{array}{c}-0.000 \\
(0.000)\end{array}$ & $\begin{array}{l}-0.000 \\
(0.000)\end{array}$ & $\begin{array}{c}-0.000 \\
(0.000)\end{array}$ & $\begin{array}{c}0.000 \\
(0.000)\end{array}$ & $\begin{array}{c}0.000 \\
(0.000)\end{array}$ & $\begin{array}{l}-0.000 \\
(0.001)\end{array}$ \\
\hline SD of unemployment rate & $\begin{array}{c}-0.375 \\
(0.398)\end{array}$ & $\begin{array}{l}-0.031 \\
(0.397)\end{array}$ & $\begin{array}{c}-0.265 \\
(0.460)\end{array}$ & $\begin{array}{c}0.191 \\
(0.513)\end{array}$ & $\begin{array}{c}-0.268 \\
(0.492)\end{array}$ & $\begin{array}{c}-0.066 \\
(0.637)\end{array}$ \\
\hline SD of inflation & $\begin{array}{c}27.89 \\
(60.96)\end{array}$ & $\begin{array}{l}165.2 * * \\
(82.73)\end{array}$ & $\begin{array}{l}-94.28 \\
(63.69)\end{array}$ & $\begin{array}{l}-111.5 \\
(76.63)\end{array}$ & $\begin{array}{c}-191.5 * * \\
(97.54)\end{array}$ & $\begin{array}{c}49.98 \\
(73.19)\end{array}$ \\
\hline N observations & 691 & 570 & 607 & & & \\
\hline $\mathrm{N}$ country-country id & 261 & 222 & 230 & & & \\
\hline $\mathrm{N}$ instruments & 231 & 255 & 230 & & & \\
\hline AR (1) p-value & 0.00 & 0.01 & 0.00 & & & \\
\hline AR (2) p-value & 0.27 & 0.35 & 0.71 & & & \\
\hline Hansen p-value & 0.97 & 1.00 & 0.98 & & & \\
\hline
\end{tabular}

Robust standard errors are in parentheses $* * * \mathrm{p}<0.01, * * \mathrm{p}<0.05, * \mathrm{p}<0.1$ 
Table 11. Portfolio investments, 2001-06, share in the range of 1 and 7 percent

\begin{tabular}{|c|c|c|c|c|c|c|}
\hline \multirow[b]{2}{*}{ VARIABLES } & \multicolumn{3}{|c|}{ high concentration } & \multicolumn{3}{|c|}{ Interaction term } \\
\hline & $\begin{array}{l}\text { total } \\
(1)\end{array}$ & $\begin{array}{c}\text { equity } \\
\text { (2) }\end{array}$ & $\begin{array}{l}\text { debt } \\
(3)\end{array}$ & $\begin{array}{l}\text { total } \\
(4)\end{array}$ & $\begin{array}{c}\text { equity } \\
(5)\end{array}$ & $\begin{array}{l}\text { debt } \\
(6)\end{array}$ \\
\hline portfoli investment & $\begin{array}{c}0.875^{* * *} \\
(0.022)\end{array}$ & $\begin{array}{c}0.897 * * * \\
(0.017)\end{array}$ & $\begin{array}{c}0.910^{* * *} \\
(0.017)\end{array}$ & - & - & - \\
\hline short-term interest rate & $\begin{array}{c}0.137 \\
(0.091)\end{array}$ & $\begin{array}{c}0.079 \\
(0.146)\end{array}$ & $\begin{array}{c}0.003 \\
(0.069)\end{array}$ & $\begin{array}{l}-0.101 \\
(0.100)\end{array}$ & $\begin{array}{l}-0.022 \\
(0.152)\end{array}$ & $\begin{array}{c}-0.072 \\
(0.080)\end{array}$ \\
\hline long-term interest rate & $\begin{array}{c}-0.153 \\
(0.157)\end{array}$ & $\begin{array}{l}-0.181 \\
(0.211)\end{array}$ & $\begin{array}{c}0.105 \\
(0.099)\end{array}$ & $\begin{array}{c}0.095 \\
(0.135)\end{array}$ & $\begin{array}{c}0.058 \\
(0.192)\end{array}$ & $\begin{array}{c}0.012 \\
(0.092)\end{array}$ \\
\hline stock index & $\begin{array}{c}0.000 \\
(0.000)\end{array}$ & $\begin{array}{c}0.000 \\
(0.000)\end{array}$ & $\begin{array}{l}-0.000 \\
(0.000)\end{array}$ & $\begin{array}{l}-0.000 \\
(0.000)\end{array}$ & $\begin{array}{l}-0.000 \\
(0.000)\end{array}$ & $\begin{array}{c}0.000 \\
(0.000)\end{array}$ \\
\hline growth of stock index & $\begin{array}{c}8.579 * * \\
(4.165)\end{array}$ & $\begin{array}{c}30.60 * * * \\
(6.886)\end{array}$ & $\begin{array}{c}2.123 \\
(3.558)\end{array}$ & $\begin{array}{l}-1.074 \\
(4.687)\end{array}$ & $\begin{array}{c}-19.72 * * \\
(8.965)\end{array}$ & $\begin{array}{c}1.756 \\
(4.117)\end{array}$ \\
\hline unemployment rate & $\begin{array}{l}-0.015 \\
(0.024)\end{array}$ & $\begin{array}{l}-0.041 \\
(0.028)\end{array}$ & $\begin{array}{l}-0.017 \\
(0.018)\end{array}$ & $\begin{array}{l}0.008 \\
(0.027)\end{array}$ & $\begin{array}{c}0.023 \\
(0.033)\end{array}$ & $\begin{array}{c}0.001 \\
(0.019)\end{array}$ \\
\hline inflation & $\begin{array}{l}-25.01 \\
(22.10)\end{array}$ & $\begin{array}{l}-127.5^{*} \\
(72.97)\end{array}$ & $\begin{array}{l}-24.78 \\
(22.09)\end{array}$ & $\begin{array}{c}59.28^{* *} \\
(30.12)\end{array}$ & $\begin{array}{l}176.4 * * \\
(82.03)\end{array}$ & $\begin{array}{c}21.25 \\
(30.65)\end{array}$ \\
\hline real effective exchange rate & $\begin{array}{l}-0.009 \\
(0.011)\end{array}$ & $\begin{array}{l}-0.029^{*} \\
(0.017)\end{array}$ & $\begin{array}{l}-0.005 \\
(0.007)\end{array}$ & $\begin{array}{c}0.009 * * \\
(0.004)\end{array}$ & $\begin{array}{l}0.012^{*} \\
(0.006)\end{array}$ & $\begin{array}{l}0.007^{*} \\
(0.004)\end{array}$ \\
\hline GDP growth & $\begin{array}{c}14.80 * * * \\
(5.724)\end{array}$ & $\begin{array}{c}6.667 \\
(5.167)\end{array}$ & $\begin{array}{c}10.19 * * * \\
(4.413)\end{array}$ & $\begin{array}{l}-5.706 \\
(5.041)\end{array}$ & $\begin{array}{l}-2.811 \\
(6.194)\end{array}$ & $\begin{array}{l}-7.431 \\
(4.935)\end{array}$ \\
\hline $\begin{array}{l}\text { current account to GDP } \\
\text { ratio }\end{array}$ & $\begin{array}{c}1.766 \\
(1.274)\end{array}$ & $\begin{array}{l}-1.948 \\
(1.995)\end{array}$ & $\begin{array}{c}1.767 \\
(1.317)\end{array}$ & $\begin{array}{l}-0.716 \\
(1.404)\end{array}$ & $\begin{array}{l}3.785^{*} \\
(2.146)\end{array}$ & $\begin{array}{c}-3.440 * * \\
(1.694)\end{array}$ \\
\hline $\begin{array}{l}\text { government debt to GDP } \\
\text { ratio }\end{array}$ & $\begin{array}{c}0.167 \\
(0.211)\end{array}$ & $\begin{array}{l}-0.094 \\
(0.212)\end{array}$ & $\begin{array}{c}0.117 \\
(0.202)\end{array}$ & $\begin{array}{l}-0.149 \\
(0.229)\end{array}$ & $\begin{array}{c}0.138 \\
(0.248)\end{array}$ & $\begin{array}{l}-0.259 \\
(0.225)\end{array}$ \\
\hline $\begin{array}{l}\text { SD of short-term interest } \\
\text { rate }\end{array}$ & $\begin{array}{l}-0.490 \\
(0.340)\end{array}$ & $\begin{array}{c}0.262 \\
(0.814)\end{array}$ & $\begin{array}{c}0.204 \\
(0.339)\end{array}$ & $\begin{array}{l}1.010^{* *} \\
(0.495)\end{array}$ & $\begin{array}{l}-0.038 \\
(0.980)\end{array}$ & $\begin{array}{l}-0.363 \\
(0.466)\end{array}$ \\
\hline $\begin{array}{l}\text { SD of long-term interest } \\
\text { rate }\end{array}$ & $\begin{array}{c}1.305 \\
(1.782)\end{array}$ & $\begin{array}{l}3.539^{*} \\
(2.135)\end{array}$ & $\begin{array}{l}-0.267 \\
(0.861)\end{array}$ & $\begin{array}{l}-2.225 \\
(2.059)\end{array}$ & $\begin{array}{l}-3.801 * \\
(2.309)\end{array}$ & $\begin{array}{c}0.167 \\
(0.982)\end{array}$ \\
\hline SD of stock index growth & $\begin{array}{l}1.073 \\
(3.969)\end{array}$ & $\begin{array}{c}5.643 \\
(5.842)\end{array}$ & $\begin{array}{l}-0.653 \\
(3.646)\end{array}$ & $\begin{array}{c}0.125 \\
(4.366)\end{array}$ & $\begin{array}{l}-2.105 \\
(6.124)\end{array}$ & $\begin{array}{l}3.446 \\
(4.433)\end{array}$ \\
\hline SD of stock index & $\begin{array}{l}-0.000 \\
(0.001)\end{array}$ & $\begin{array}{c}0.000 \\
(0.001)\end{array}$ & $\begin{array}{l}0.001^{*} \\
(0.000)\end{array}$ & $\begin{array}{c}0.000 \\
(0.001)\end{array}$ & $\begin{array}{l}-0.000 \\
(0.001)\end{array}$ & $\begin{array}{l}-0.001 \\
(0.001)\end{array}$ \\
\hline SD of unemployment rate & $\begin{array}{c}1.615 * * * \\
(0.461)\end{array}$ & $\begin{array}{c}1.580 * * * \\
(0.621)\end{array}$ & $\begin{array}{c}0.250 \\
(0.435)\end{array}$ & $\begin{array}{c}-1.399 * * \\
(0.553)\end{array}$ & $\begin{array}{c}-1.573 * * \\
(0.659)\end{array}$ & $\begin{array}{l}-0.211 \\
(0.503)\end{array}$ \\
\hline SD of inflation & $\begin{array}{c}90.39 \\
(56.83) \\
\end{array}$ & $\begin{array}{c}49.33 \\
(73.23) \\
\end{array}$ & $\begin{array}{c}1.673 \\
(53.69) \\
\end{array}$ & $\begin{array}{c}25.26 \\
(40.96) \\
\end{array}$ & $\begin{array}{c}91.74 \\
(74.70)\end{array}$ & $\begin{array}{l}-31.27 \\
(32.37)\end{array}$ \\
\hline $\mathrm{N}$ observations & 567 & 522 & 555 & & & \\
\hline $\mathrm{N}$ country-country id & 230 & 217 & 225 & & & \\
\hline $\mathrm{N}$ instruments & 246 & 240 & 246 & & & \\
\hline AR (1) p-value & 0.03 & 0.00 & 0.00 & & & \\
\hline AR (2) p-value & 0.55 & 0.97 & 0.30 & & & \\
\hline Hansen p-value & 0.99 & 1.00 & 0.99 & & & \\
\hline
\end{tabular}

Robust standard errors are in parentheses

$$
* * * \mathrm{p}<0.01, * * \mathrm{p}<0.05, * \mathrm{p}<0.1
$$


Table 12. Portfolio investments, 2001-06, share equal to or above 7 percent

\begin{tabular}{|c|c|c|c|c|c|c|}
\hline \multirow[b]{2}{*}{ VARIABLES } & \multicolumn{3}{|c|}{ high concentration } & \multicolumn{3}{|c|}{ Interaction term } \\
\hline & $\begin{array}{c}\text { total } \\
(1)\end{array}$ & $\begin{array}{c}\text { equity } \\
\text { (2) }\end{array}$ & $\begin{array}{c}\text { debt } \\
(3) \\
\end{array}$ & $\begin{array}{c}\text { total } \\
(4)\end{array}$ & $\begin{array}{c}\text { equity } \\
(5)\end{array}$ & $\begin{array}{c}\text { debt } \\
(6) \\
\end{array}$ \\
\hline portfoli investment & $\begin{array}{c}0.847 * * * \\
(0.031)\end{array}$ & $\begin{array}{c}0.900 * * * \\
(0.029)\end{array}$ & $\begin{array}{c}0.904 * * * \\
(0.018)\end{array}$ & - & - & - \\
\hline short-term interest rate & $\begin{array}{l}-0.011 \\
(0.187)\end{array}$ & $\begin{array}{l}-0.261 \\
(0.211)\end{array}$ & $\begin{array}{c}0.162 \\
(0.141)\end{array}$ & $\begin{array}{c}-0.039 \\
(0.111)\end{array}$ & $\begin{array}{c}0.058 \\
(0.136)\end{array}$ & $\begin{array}{c}-0.096 \\
(0.093)\end{array}$ \\
\hline long-term interest rate & $\begin{array}{c}0.343 \\
(0.415)\end{array}$ & $\begin{array}{c}0.639 \\
(0.435)\end{array}$ & $\begin{array}{l}-0.197 \\
(0.259)\end{array}$ & $\begin{array}{c}-0.138 \\
(0.281)\end{array}$ & $\begin{array}{c}0.039 \\
(0.280)\end{array}$ & $\begin{array}{c}0.096 \\
(0.201)\end{array}$ \\
\hline stock index & $\begin{array}{c}0.000 \\
(0.000)\end{array}$ & $\begin{array}{c}-0.000 \\
(0.000)\end{array}$ & $\begin{array}{c}0.000 \\
(0.000)\end{array}$ & $\begin{array}{l}-0.000 \\
(0.000)\end{array}$ & $\begin{array}{c}-0.000 \\
(0.000)\end{array}$ & $\begin{array}{c}0.000 \\
(0.000)\end{array}$ \\
\hline growth of stock index & $\begin{array}{l}15.72 * * \\
(7.309)\end{array}$ & $\begin{array}{c}20.92 * * \\
(8.973)\end{array}$ & $\begin{array}{l}-6.303 \\
(4.764)\end{array}$ & $\begin{array}{c}-13.83 * \\
(7.403)\end{array}$ & $\begin{array}{l}-6.927 \\
(8.772)\end{array}$ & $\begin{array}{c}-0.698 \\
(4.743)\end{array}$ \\
\hline unemployment rate & $\begin{array}{c}-0.002 \\
(0.045)\end{array}$ & $\begin{array}{c}-0.052 \\
(0.043)\end{array}$ & $\begin{array}{c}0.002 \\
(0.017)\end{array}$ & $\begin{array}{l}-0.025 \\
(0.061)\end{array}$ & $\begin{array}{c}-0.018 \\
(0.056)\end{array}$ & $\begin{array}{c}0.024 \\
(0.034)\end{array}$ \\
\hline inflation & $\begin{array}{c}5.759 \\
(76.88)\end{array}$ & $\begin{array}{c}25.12 \\
(55.39)\end{array}$ & $\begin{array}{c}-86.54 * * \\
(37.00)\end{array}$ & $\begin{array}{l}-5.584 \\
(82.79)\end{array}$ & $\begin{array}{c}13.64 \\
(63.11)\end{array}$ & $\begin{array}{l}75.97 * \\
(40.60)\end{array}$ \\
\hline real effective exchange rate & $\begin{array}{c}-0.023 \\
(0.016)\end{array}$ & $\begin{array}{c}-0.039 * * \\
(0.020)\end{array}$ & $\begin{array}{c}-0.001 \\
(0.013)\end{array}$ & $\begin{array}{c}0.019 \\
(0.012)\end{array}$ & $\begin{array}{l}-0.000 \\
(0.012)\end{array}$ & $\begin{array}{c}-0.003 \\
(0.008)\end{array}$ \\
\hline GDP growth & $\begin{array}{c}13.10 \\
(11.06)\end{array}$ & $\begin{array}{c}7.680 \\
(10.52)\end{array}$ & $\begin{array}{c}4.765 \\
(5.537)\end{array}$ & $\begin{array}{c}-16.74 \\
(13.50)\end{array}$ & $\begin{array}{c}-14.84 \\
(12.98)\end{array}$ & $\begin{array}{c}-5.278 \\
(7.207)\end{array}$ \\
\hline $\begin{array}{l}\text { current account to GDP } \\
\text { ratio }\end{array}$ & $\begin{array}{l}-0.277 \\
(2.216)\end{array}$ & $\begin{array}{c}1.043 \\
(3.108)\end{array}$ & $\begin{array}{c}1.204 \\
(2.144)\end{array}$ & $\begin{array}{l}-0.593 \\
(2.362)\end{array}$ & $\begin{array}{c}3.092 \\
(3.345)\end{array}$ & $\begin{array}{l}-2.986 \\
(1.909)\end{array}$ \\
\hline $\begin{array}{l}\text { government debt to GDP } \\
\text { ratio }\end{array}$ & $\begin{array}{l}-0.384 \\
(0.333)\end{array}$ & $\begin{array}{l}-0.568 \\
(0.505)\end{array}$ & $\begin{array}{c}0.340 \\
(0.413)\end{array}$ & $\begin{array}{c}0.877 \\
(0.801)\end{array}$ & $\begin{array}{l}2.271 * \\
(1.176)\end{array}$ & $\begin{array}{l}-0.827 \\
(0.514)\end{array}$ \\
\hline $\begin{array}{l}\text { SD of short-term interest } \\
\text { rate }\end{array}$ & $\begin{array}{l}-1.616 * * * \\
(0.613)\end{array}$ & $\begin{array}{l}-0.602 \\
(0.678)\end{array}$ & $\begin{array}{l}-0.912 * \\
(0.531)\end{array}$ & $\begin{array}{l}1.473 * \\
(0.778)\end{array}$ & $\begin{array}{c}0.824 \\
(0.827)\end{array}$ & $\begin{array}{c}0.883 \\
(0.668)\end{array}$ \\
\hline $\begin{array}{l}\mathrm{SD} \text { of long-term interest } \\
\text { rate }\end{array}$ & $\begin{array}{l}-0.096 \\
(1.276)\end{array}$ & $\begin{array}{c}0.838 \\
(1.566)\end{array}$ & $\begin{array}{l}-0.780 \\
(0.963)\end{array}$ & $\begin{array}{l}-0.913 \\
(0.978)\end{array}$ & $\begin{array}{c}0.943 \\
(1.580)\end{array}$ & $\begin{array}{c}0.295 \\
(0.832)\end{array}$ \\
\hline SD of stock index growth & $\begin{array}{c}5.438 \\
(7.180)\end{array}$ & $\begin{array}{c}5.745 \\
(5.941)\end{array}$ & $\begin{array}{l}-1.634 \\
(4.226)\end{array}$ & $\begin{array}{c}1.077 \\
(9.382)\end{array}$ & $\begin{array}{l}-6.486 \\
(8.815)\end{array}$ & $\begin{array}{c}6.633 \\
(6.562)\end{array}$ \\
\hline SD of stock index & $\begin{array}{c}0.000 \\
(0.000)\end{array}$ & $\begin{array}{c}0.001 \\
(0.000)\end{array}$ & $\begin{array}{l}-0.000 \\
(0.000)\end{array}$ & $\begin{array}{l}-0.000 \\
(0.000)\end{array}$ & $\begin{array}{l}-0.001 \\
(0.001)\end{array}$ & $\begin{array}{l}-0.001 \\
(0.000)\end{array}$ \\
\hline SD of unemployment rate & $\begin{array}{c}1.547 * * * \\
(0.524)\end{array}$ & $\begin{array}{c}2.076 * * * \\
(0.504)\end{array}$ & $\begin{array}{l}-0.270 \\
(0.552)\end{array}$ & $\begin{array}{c}-1.774 * * \\
(0.719)\end{array}$ & $\begin{array}{c}-2.088 * * * \\
(0.657)\end{array}$ & $\begin{array}{c}0.262 \\
(0.649)\end{array}$ \\
\hline SD of inflation & $\begin{array}{c}-9.271 \\
(110.4)\end{array}$ & $\begin{array}{c}-81.26 \\
(93.24) \\
\end{array}$ & $\begin{array}{c}14.70 \\
(97.25) \\
\end{array}$ & $\begin{array}{l}-149.1 \\
(124.9)\end{array}$ & $\begin{array}{l}-72.06 \\
(104.4)\end{array}$ & $\begin{array}{l}-47.96 \\
(105.7)\end{array}$ \\
\hline $\mathrm{N}$ observations & 289 & 292 & 286 & & & \\
\hline $\mathrm{N}$ country-country id & 108 & 113 & 107 & & & \\
\hline $\mathrm{N}$ instruments & 126 & 129 & 126 & & & \\
\hline AR (1) p-value & 0.04 & 0.03 & 0.02 & & & \\
\hline AR (2) p-value & 0.65 & 0.62 & 0.11 & & & \\
\hline Hansen p-value & 0.99 & 0.99 & 1.00 & & & \\
\hline
\end{tabular}

Robust standard errors are in parentheses $* * * \mathrm{p}<0.01, * * \mathrm{p}<0.05, * \mathrm{p}<0.1$ 
Table 13. Portfolio investments, 2007-10

\begin{tabular}{|c|c|c|c|c|c|c|}
\hline \multirow[b]{2}{*}{ VARIABLES } & \multicolumn{3}{|c|}{ high concentration } & \multicolumn{3}{|c|}{ Interaction term } \\
\hline & $\begin{array}{l}\text { total } \\
(1)\end{array}$ & $\begin{array}{l}\text { equity } \\
\text { (2) }\end{array}$ & $\begin{array}{l}\text { debt } \\
(3)\end{array}$ & $\begin{array}{l}\text { total } \\
(4)\end{array}$ & $\begin{array}{c}\text { equity } \\
(5)\end{array}$ & $\begin{array}{l}\text { debt } \\
(6)\end{array}$ \\
\hline portfoli investment & $\begin{array}{c}0.910 * * * \\
(0.019)\end{array}$ & $\begin{array}{c}0.936^{* * *} \\
(0.022)\end{array}$ & $\begin{array}{c}0.913^{* * *} \\
(0.019)\end{array}$ & - & - & - \\
\hline short-term interest rate & $\begin{array}{l}-0.146^{*} \\
(0.085)\end{array}$ & $\begin{array}{l}-0.188 \\
(0.119)\end{array}$ & $\begin{array}{l}-0.054 \\
(0.054)\end{array}$ & $\begin{array}{c}0.185 \\
(0.116)\end{array}$ & $\begin{array}{c}0.238 \\
(0.160)\end{array}$ & $\begin{array}{c}0.062 \\
(0.070)\end{array}$ \\
\hline long-term interest rate & $\begin{array}{l}0.254^{*} \\
(0.147)\end{array}$ & $\begin{array}{c}0.267 \\
(0.193)\end{array}$ & $\begin{array}{c}0.143 \\
(0.113)\end{array}$ & $\begin{array}{l}-0.305 \\
(0.201)\end{array}$ & $\begin{array}{l}-0.398 \\
(0.258)\end{array}$ & $\begin{array}{l}-0.150 \\
(0.141)\end{array}$ \\
\hline stock index & $\begin{array}{c}-0.000 * * \\
(0.000)\end{array}$ & $\begin{array}{l}-0.000 \\
(0.000)\end{array}$ & $\begin{array}{c}-0.000 * * \\
(0.000)\end{array}$ & $\begin{array}{c}0.000 \\
(0.000)\end{array}$ & $\begin{array}{l}-0.000 \\
(0.000)\end{array}$ & $\begin{array}{l}0.000 \\
(0.000)\end{array}$ \\
\hline growth of stock index & $\begin{array}{l}-1.003 \\
(3.436)\end{array}$ & $\begin{array}{l}6.635 \\
(5.198)\end{array}$ & $\begin{array}{l}-1.189 \\
(3.172)\end{array}$ & $\begin{array}{c}0.906 \\
(3.764)\end{array}$ & $\begin{array}{l}4.683 \\
(5.745)\end{array}$ & $\begin{array}{l}-1.796 \\
(3.474)\end{array}$ \\
\hline unemployment rate & $\begin{array}{l}-0.019 \\
(0.018)\end{array}$ & $\begin{array}{l}-0.022 \\
(0.017)\end{array}$ & $\begin{array}{l}-0.014 \\
(0.020)\end{array}$ & $\begin{array}{c}0.016 \\
(0.022)\end{array}$ & $\begin{array}{l}0.023 \\
(0.025)\end{array}$ & $\begin{array}{c}0.014 \\
(0.024)\end{array}$ \\
\hline inflation & $\begin{array}{c}-32.22 * * * \\
(12.37)\end{array}$ & $\begin{array}{l}-47.03 * * \\
(20.26)\end{array}$ & $\begin{array}{c}-31.18 * * \\
(15.49)\end{array}$ & $\begin{array}{r}36.14^{* *} \\
(15.57)\end{array}$ & $\begin{array}{r}51.77 * * \\
(23.40)\end{array}$ & $\begin{array}{c}21.74 \\
(19.78)\end{array}$ \\
\hline real effective exchange rate & $\begin{array}{l}-0.007^{*} \\
(0.004)\end{array}$ & $\begin{array}{l}-0.001 \\
(0.004)\end{array}$ & $\begin{array}{l}-0.008^{*} \\
(0.004)\end{array}$ & $\begin{array}{l}0.004 \\
(0.004)\end{array}$ & $\begin{array}{l}0.008^{*} \\
(0.004)\end{array}$ & $\begin{array}{l}0.001 \\
(0.004)\end{array}$ \\
\hline GDP growth & $\begin{array}{l}-0.844 \\
(2.290)\end{array}$ & $\begin{array}{l}4.010^{*} \\
(2.410)\end{array}$ & $\begin{array}{l}-4.403^{*} \\
(2.317)\end{array}$ & $\begin{array}{c}2.364 \\
(2.564)\end{array}$ & $\begin{array}{l}-3.867 \\
(2.716)\end{array}$ & $\begin{array}{l}6.326 * * \\
(2.480)\end{array}$ \\
\hline $\begin{array}{l}\text { current account to GDP } \\
\text { ratio }\end{array}$ & $\begin{array}{l}-0.962 \\
(0.834)\end{array}$ & $\begin{array}{l}-0.681 \\
(1.140)\end{array}$ & $\begin{array}{l}-0.084 \\
(0.903)\end{array}$ & $\begin{array}{l}1.548 \\
(1.094)\end{array}$ & $\begin{array}{l}0.755 \\
(1.419)\end{array}$ & $\begin{array}{l}0.430 \\
(1.263)\end{array}$ \\
\hline $\begin{array}{l}\text { government debt to GDP } \\
\text { ratio }\end{array}$ & $\begin{array}{l}-0.111 \\
(0.102)\end{array}$ & $\begin{array}{c}0.193 \\
(0.138)\end{array}$ & $\begin{array}{l}-0.016 \\
(0.110)\end{array}$ & $\begin{array}{c}0.225 \\
(0.149)\end{array}$ & $\begin{array}{c}0.250 \\
(0.172)\end{array}$ & $\begin{array}{c}0.053 \\
(0.148)\end{array}$ \\
\hline $\begin{array}{l}\mathrm{SD} \text { of short-term interest } \\
\text { rate }\end{array}$ & $\begin{array}{c}0.354 \\
(0.225)\end{array}$ & $\begin{array}{c}0.348 \\
(0.348)\end{array}$ & $\begin{array}{c}0.149 \\
(0.291)\end{array}$ & $\begin{array}{l}-0.173 \\
(0.280)\end{array}$ & $\begin{array}{l}-0.424 \\
(0.441)\end{array}$ & $\begin{array}{l}0.069 \\
(0.357)\end{array}$ \\
\hline $\begin{array}{l}\text { SD of long-term interest } \\
\text { rate }\end{array}$ & $\begin{array}{l}-0.574^{*} \\
(0.294)\end{array}$ & $\begin{array}{l}-0.395 \\
(0.395)\end{array}$ & $\begin{array}{c}-0.628 * * \\
(0.290)\end{array}$ & $\begin{array}{c}0.409 \\
(0.395)\end{array}$ & $\begin{array}{c}0.633 \\
(0.518)\end{array}$ & $\begin{array}{l}0.523 \\
(0.342)\end{array}$ \\
\hline SD of stock index growth & $\begin{array}{l}-1.565 \\
(3.054)\end{array}$ & $\begin{array}{l}-0.368 \\
(3.561)\end{array}$ & $\begin{array}{l}-1.136 \\
(3.122)\end{array}$ & $\begin{array}{c}4.565 \\
(3.729)\end{array}$ & $\begin{array}{l}-1.187 \\
(4.582)\end{array}$ & $\begin{array}{c}2.904 \\
(4.086)\end{array}$ \\
\hline SD of stock index & $\begin{array}{c}0.000 \\
(0.000)\end{array}$ & $\begin{array}{l}-0.000 \\
(0.000)\end{array}$ & $\begin{array}{c}0.000 \\
(0.000)\end{array}$ & $\begin{array}{l}-0.000 \\
(0.000)\end{array}$ & $\begin{array}{c}0.000 \\
(0.000)\end{array}$ & $\begin{array}{l}-0.000 \\
(0.000)\end{array}$ \\
\hline SD of unemployment rate & $\begin{array}{c}0.076 \\
(0.132)\end{array}$ & $\begin{array}{l}-0.079 \\
(0.140)\end{array}$ & $\begin{array}{l}-0.011 \\
(0.155)\end{array}$ & $\begin{array}{c}0.059 \\
(0.166)\end{array}$ & $\begin{array}{l}0.285 \\
(0.195)\end{array}$ & $\begin{array}{l}0.203 \\
(0.203)\end{array}$ \\
\hline SD of inflation & $\begin{array}{l}-7.374 \\
(30.46)\end{array}$ & $\begin{array}{c}54.66 \\
(49.62) \\
\end{array}$ & $\begin{array}{c}6.557 \\
(33.54) \\
\end{array}$ & $\begin{array}{c}4.375 \\
(38.79) \\
\end{array}$ & $\begin{array}{l}-25.56 \\
(60.85) \\
\end{array}$ & $\begin{array}{l}017.08 \\
(43.77) \\
\end{array}$ \\
\hline $\mathrm{N}$ observations & 1,531 & 1,390 & 1,437 & & & \\
\hline $\mathrm{N}$ country-country id & 491 & 464 & 470 & & & \\
\hline $\mathrm{N}$ instruments & 365 & 362 & 268 & & & \\
\hline AR (1) p-value & 0.00 & 0.00 & 0.00 & & & \\
\hline AR (2) p-value & 0.38 & 0.45 & 0.54 & & & \\
\hline Hansen p-value & 0.23 & 0.59 & 0.32 & & & \\
\hline
\end{tabular}

Robust standard errors are in parentheses $* * * \mathrm{p}<0.01, * * \mathrm{p}<0.05, * \mathrm{p}<0.1$ 
Table 14. Portfolio investments, 2007-10, share below 1 percent

\begin{tabular}{|c|c|c|c|c|c|c|}
\hline \multirow[b]{2}{*}{ VARIABLES } & \multicolumn{3}{|c|}{ high concentration } & \multicolumn{3}{|c|}{ Interaction term } \\
\hline & $\begin{array}{l}\text { total } \\
(1)\end{array}$ & $\begin{array}{c}\text { equity } \\
\text { (2) }\end{array}$ & $\begin{array}{c}\text { debt } \\
(3)\end{array}$ & $\begin{array}{l}\text { total } \\
(4)\end{array}$ & $\begin{array}{c}\text { equity } \\
(5)\end{array}$ & $\begin{array}{l}\text { debt } \\
(6)\end{array}$ \\
\hline portfoli investment & $\begin{array}{c}0.866 * * * \\
(0.026)\end{array}$ & $\begin{array}{c}0.887 * * * \\
(0.034)\end{array}$ & $\begin{array}{c}0.883 * * * \\
(0.023)\end{array}$ & - & - & - \\
\hline short-term interest rate & $\begin{array}{c}-0.199^{*} \\
(0.110)\end{array}$ & $\begin{array}{l}-0.222 \\
(0.152)\end{array}$ & $\begin{array}{l}-0.022 \\
(0.075)\end{array}$ & $\begin{array}{l}0.236^{*} \\
(0.134)\end{array}$ & $\begin{array}{c}0.274 \\
(0.190)\end{array}$ & $\begin{array}{c}-0.015 \\
(0.087)\end{array}$ \\
\hline long-term interest rate & $\begin{array}{c}0.371 * * \\
(0.184)\end{array}$ & $\begin{array}{c}0.341 \\
(0.247)\end{array}$ & $\begin{array}{c}0.134 \\
(0.135)\end{array}$ & $\begin{array}{l}-0.367 \\
(0.230)\end{array}$ & $\begin{array}{l}-0.414 \\
(0.304)\end{array}$ & $\begin{array}{c}0.008 \\
(0.163)\end{array}$ \\
\hline stock index & $\begin{array}{l}-0.000 \\
(0.000)\end{array}$ & $\begin{array}{c}0.000 \\
(0.000)\end{array}$ & $\begin{array}{c}-0.000 * * * \\
(0.000)\end{array}$ & $\begin{array}{c}0.000 \\
(0.000)\end{array}$ & $\begin{array}{l}-0.000 \\
(0.000)\end{array}$ & $\begin{array}{c}0.000 * * * \\
(0.000)\end{array}$ \\
\hline growth of stock index & $\begin{array}{l}-3.911 \\
(4.744)\end{array}$ & $\begin{array}{c}6.204 \\
(7.474)\end{array}$ & $\begin{array}{c}-0.984 \\
(4.410)\end{array}$ & $\begin{array}{l}8.976^{*} \\
(5.300)\end{array}$ & $\begin{array}{l}12.29^{*} \\
(7.450)\end{array}$ & $\begin{array}{l}-0.401 \\
(4.650)\end{array}$ \\
\hline unemployment rate & $\begin{array}{l}-0.024 \\
(0.022)\end{array}$ & $\begin{array}{l}-0.023 \\
(0.023)\end{array}$ & $\begin{array}{l}-0.006 \\
(0.022)\end{array}$ & $\begin{array}{c}0.015 \\
(0.024)\end{array}$ & $\begin{array}{c}0.012 \\
(0.028)\end{array}$ & $\begin{array}{l}-0.015 \\
(0.026)\end{array}$ \\
\hline inflation & $\begin{array}{l}-24.66 \\
(19.22)\end{array}$ & $\begin{array}{l}-33.61 \\
(27.31)\end{array}$ & $\begin{array}{l}-7.432 \\
(22.17)\end{array}$ & $\begin{array}{c}12.84 \\
(24.24)\end{array}$ & $\begin{array}{c}40.25 \\
(29.54)\end{array}$ & $\begin{array}{l}-12.90 \\
(28.09)\end{array}$ \\
\hline real effective exchange rate & $\begin{array}{l}-0.010^{*} \\
(0.006)\end{array}$ & $\begin{array}{l}-0.009 \\
(0.006)\end{array}$ & $\begin{array}{l}-0.004 \\
(0.007)\end{array}$ & $\begin{array}{c}0.005 \\
(0.005)\end{array}$ & $\begin{array}{c}0.008 \\
(0.006)\end{array}$ & $\begin{array}{l}-0.003 \\
(0.005)\end{array}$ \\
\hline GDP growth & $\begin{array}{l}-0.689 \\
(2.653)\end{array}$ & $\begin{array}{c}4.261 \\
(2.951)\end{array}$ & $\begin{array}{l}-0.901 \\
(3.121)\end{array}$ & $\begin{array}{c}4.226 \\
(2.930)\end{array}$ & $\begin{array}{c}0.429 \\
(3.742)\end{array}$ & $\begin{array}{c}3.049 \\
(3.319)\end{array}$ \\
\hline $\begin{array}{l}\text { current account to GDP } \\
\text { ratio }\end{array}$ & $\begin{array}{l}-0.154 \\
(0.997)\end{array}$ & $\begin{array}{c}0.074 \\
(1.376)\end{array}$ & $\begin{array}{l}1.606 \\
(1.243)\end{array}$ & $\begin{array}{c}0.755 \\
(1.294)\end{array}$ & $\begin{array}{c}0.402 \\
(1.589)\end{array}$ & $\begin{array}{l}-1.676 \\
(1.581)\end{array}$ \\
\hline $\begin{array}{l}\text { government debt to GDP } \\
\text { ratio }\end{array}$ & $\begin{array}{l}-0.018 \\
(0.096)\end{array}$ & $\begin{array}{l}-0.191 \\
(0.140)\end{array}$ & $\begin{array}{l}0.148 \\
(0.122)\end{array}$ & $\begin{array}{l}-0.065 \\
(0.130)\end{array}$ & $\begin{array}{l}0.123 \\
(0.163)\end{array}$ & $\begin{array}{l}-0.317^{*} \\
(0.166)\end{array}$ \\
\hline $\begin{array}{l}\text { SD of short-term interest } \\
\text { rate }\end{array}$ & $\begin{array}{c}0.485 \\
(0.314)\end{array}$ & $\begin{array}{l}0.247 \\
(0.472)\end{array}$ & $\begin{array}{c}0.347 \\
(0.414)\end{array}$ & $\begin{array}{l}-0.185 \\
(0.372)\end{array}$ & $\begin{array}{l}-0.347 \\
(0.542)\end{array}$ & $\begin{array}{l}-0.063 \\
(0.514)\end{array}$ \\
\hline $\begin{array}{l}\mathrm{SD} \text { of long-term interest } \\
\text { rate }\end{array}$ & $\begin{array}{c}-1.089 * * \\
(0.426)\end{array}$ & $\begin{array}{l}-0.747 \\
(0.820)\end{array}$ & $\begin{array}{c}-1.425 * * * \\
(0.472)\end{array}$ & $\begin{array}{l}0.815 \\
(0.532)\end{array}$ & $\begin{array}{l}0.698 \\
(0.929)\end{array}$ & $\begin{array}{l}1.310^{* *} \\
(0.579)\end{array}$ \\
\hline SD of stock index growth & $\begin{array}{l}-3.564 \\
(3.858)\end{array}$ & $\begin{array}{l}-0.007 \\
(4.704)\end{array}$ & $\begin{array}{l}-4.124 \\
(4.392)\end{array}$ & $\begin{array}{l}11.27^{* *} \\
(4.888)\end{array}$ & $\begin{array}{c}4.074 \\
(6.306)\end{array}$ & $\begin{array}{l}7.354 \\
(5.587)\end{array}$ \\
\hline SD of stock index & $\begin{array}{l}0.000 \\
(0.000)\end{array}$ & $\begin{array}{l}-0.000^{*} \\
(0.000)\end{array}$ & $\begin{array}{l}0.000 \\
(0.000)\end{array}$ & $\begin{array}{l}-0.000 \\
(0.000)\end{array}$ & $\begin{array}{l}0.000 * * \\
(0.000)\end{array}$ & $\begin{array}{l}-0.000 \\
(0.000)\end{array}$ \\
\hline SD of unemployment rate & $\begin{array}{l}-0.031 \\
(0.175)\end{array}$ & $\begin{array}{l}0.015 \\
(0.149)\end{array}$ & $\begin{array}{l}-0.056 \\
(0.201)\end{array}$ & $\begin{array}{l}-0.056 \\
(0.201)\end{array}$ & $\begin{array}{l}0.051 \\
(0.195)\end{array}$ & $\begin{array}{c}0.177 \\
(0.262)\end{array}$ \\
\hline SD of inflation & $\begin{array}{c}92.13 * * * \\
(35.58) \\
\end{array}$ & $\begin{array}{r}78.86 \\
(60.78) \\
\end{array}$ & $\begin{array}{c}92.33 * * \\
(42.90) \\
\end{array}$ & $\begin{array}{r}92.33^{* * *} \\
(42.90) \\
\end{array}$ & $\begin{array}{l}-59.82 \\
(72.01) \\
\end{array}$ & $\begin{array}{l}-89.19^{*} \\
(53.98) \\
\end{array}$ \\
\hline $\mathrm{N}$ observations & 756 & 643 & 669 & & & \\
\hline $\mathrm{N}$ country-country id & 274 & 246 & 253 & & & \\
\hline $\mathrm{N}$ instruments & 250 & 247 & 249 & & & \\
\hline AR (1) p-value & 0.00 & 0.03 & 0.00 & & & \\
\hline AR (2) p-value & 0.62 & 0.26 & 0.82 & & & \\
\hline Hansen p-value & 0.95 & 0.96 & 0.98 & & & \\
\hline
\end{tabular}

Robust standard errors are in parentheses

$$
* * * \mathrm{p}<0.01, * * \mathrm{p}<0.05, * \mathrm{p}<0.1
$$


Table 15. Portfolio investments, 2007-10, share in the range of 1 and 7 percent

\begin{tabular}{|c|c|c|c|c|c|c|}
\hline VARIABLES & $\begin{array}{l}\text { total } \\
(1)\end{array}$ & $\begin{array}{l}\text { concentra } \\
\text { equity } \\
(2)\end{array}$ & $\begin{array}{c}\text { debt } \\
(3)\end{array}$ & $\begin{array}{c}\text { total } \\
(4)\end{array}$ & $\begin{array}{c}\text { eraction t } \\
\text { equity } \\
(5)\end{array}$ & $\begin{array}{c}\text { debt } \\
(6)\end{array}$ \\
\hline portfoli investment & $\begin{array}{c}0.864 * * * \\
(0.029)\end{array}$ & $\begin{array}{c}0.927 * * * \\
(0.017)\end{array}$ & $\begin{array}{c}0.876^{* * *} \\
(0.027)\end{array}$ & - & - & - \\
\hline short-term interest rate & $\begin{array}{l}0.098 * \\
(0.055)\end{array}$ & $\begin{array}{l}-0.073 \\
(0.076)\end{array}$ & $\begin{array}{c}0.139 * * \\
(0.057)\end{array}$ & $\begin{array}{c}-0.178 * * \\
(0.078)\end{array}$ & $\begin{array}{c}-0.006 \\
(0.093)\end{array}$ & $\begin{array}{c}-0.295 * * * \\
(0.081)\end{array}$ \\
\hline long-term interest rate & $\begin{array}{l}-0.142 \\
(0.093)\end{array}$ & $\begin{array}{c}0.068 \\
(0.134)\end{array}$ & $\begin{array}{c}-0.229 * * \\
(0.097)\end{array}$ & $\begin{array}{c}0.322 * * * \\
(0.125)\end{array}$ & $\begin{array}{c}0.062 \\
(0.154)\end{array}$ & $\begin{array}{c}0.510 * * * \\
(0.140)\end{array}$ \\
\hline stock index & $\begin{array}{c}0.000 \\
(0.000)\end{array}$ & $\begin{array}{l}-0.000 \\
(0.000)\end{array}$ & $\begin{array}{c}0.000 \\
(0.000)\end{array}$ & $\begin{array}{c}-0.000 \\
(0.000)\end{array}$ & $\begin{array}{c}0.000 \\
(0.000)\end{array}$ & $\begin{array}{c}-0.000 * * \\
(0.000)\end{array}$ \\
\hline growth of stock index & $\begin{array}{c}2.136 \\
(2.487)\end{array}$ & $\begin{array}{c}11.69 * * * \\
(4.324)\end{array}$ & $\begin{array}{l}4.324^{*} \\
(2.531)\end{array}$ & $\begin{array}{l}-2.922 \\
(2.509)\end{array}$ & $\begin{array}{l}-1.139 \\
(4.065)\end{array}$ & $\begin{array}{c}-8.008 * * * \\
(2.883)\end{array}$ \\
\hline unemployment rate & $\begin{array}{c}-0.018 \\
(0.022)\end{array}$ & $\begin{array}{l}-0.039 \\
(0.028)\end{array}$ & $\begin{array}{c}0.026 \\
(0.023)\end{array}$ & $\begin{array}{c}0.001 \\
(0.033)\end{array}$ & $\begin{array}{c}-0.010 \\
(0.036)\end{array}$ & $\begin{array}{l}-0.039 \\
(0.034)\end{array}$ \\
\hline inflation & $\begin{array}{c}0.172 \\
(13.31)\end{array}$ & $\begin{array}{l}-34.57 \\
(27.40)\end{array}$ & $\begin{array}{l}-14.47 \\
(13.15)\end{array}$ & $\begin{array}{c}-21.42 \\
(15.08)\end{array}$ & $\begin{array}{c}46.64 \\
(32.39)\end{array}$ & $\begin{array}{l}-20.92 \\
(18.98)\end{array}$ \\
\hline real effective exchange rate & $\begin{array}{c}0.009 \\
(0.006)\end{array}$ & $\begin{array}{c}0.018 * * * \\
(0.007)\end{array}$ & $\begin{array}{l}-0.007 \\
(0.007)\end{array}$ & $\begin{array}{c}-0.002 \\
(0.004)\end{array}$ & $\begin{array}{c}-0.001 \\
(0.004)\end{array}$ & $\begin{array}{c}0.003 \\
(0.004)\end{array}$ \\
\hline GDP growth & $\begin{array}{c}1.906 \\
(5.818)\end{array}$ & $\begin{array}{c}3.550 \\
(3.338)\end{array}$ & $\begin{array}{l}-0.950 \\
(3.158)\end{array}$ & $\begin{array}{c}2.259 \\
(5.987)\end{array}$ & $\begin{array}{l}-1.302 \\
(3.659)\end{array}$ & $\begin{array}{c}4.011 \\
(2.951)\end{array}$ \\
\hline $\begin{array}{l}\text { current account to GDP } \\
\text { ratio }\end{array}$ & $\begin{array}{l}-0.420 \\
(0.879)\end{array}$ & $\begin{array}{l}-2.045^{*} \\
(1.118)\end{array}$ & $\begin{array}{c}0.021 \\
(1.087)\end{array}$ & $\begin{array}{c}0.859 \\
(1.061)\end{array}$ & $\begin{array}{c}1.735 \\
(1.299)\end{array}$ & $\begin{array}{l}-0.231 \\
(1.322)\end{array}$ \\
\hline $\begin{array}{l}\text { government debt to GDP } \\
\text { ratio }\end{array}$ & $\begin{array}{l}-0.362 \\
(0.229)\end{array}$ & $\begin{array}{l}-0.175 \\
(0.215)\end{array}$ & $\begin{array}{c}-0.732 * * * \\
(0.253)\end{array}$ & $\begin{array}{c}0.348 \\
(0.251)\end{array}$ & $\begin{array}{c}0.103 \\
(0.236)\end{array}$ & $\begin{array}{l}0.704 * * \\
(0.281)\end{array}$ \\
\hline $\begin{array}{l}\text { SD of short-term interest } \\
\text { rate }\end{array}$ & $\begin{array}{c}0.226 \\
(0.226)\end{array}$ & $\begin{array}{c}0.168 \\
(0.313)\end{array}$ & $\begin{array}{c}0.382 \\
(0.286)\end{array}$ & $\begin{array}{l}-0.294 \\
(0.287)\end{array}$ & $\begin{array}{l}-0.584 \\
(0.408)\end{array}$ & $\begin{array}{l}-0.304 \\
(0.374)\end{array}$ \\
\hline $\begin{array}{l}\text { SD of long-term interest } \\
\text { rate }\end{array}$ & $\begin{array}{c}0.276 \\
(0.245)\end{array}$ & $\begin{array}{c}0.208 \\
(0.280)\end{array}$ & $\begin{array}{c}0.306 \\
(0.252)\end{array}$ & $\begin{array}{l}-0.442 \\
(0.326)\end{array}$ & $\begin{array}{l}-0.189 \\
(0.329)\end{array}$ & $\begin{array}{l}-0.712 * * \\
(0.299)\end{array}$ \\
\hline SD of stock index growth & $\begin{array}{c}4.480 \\
(2.926)\end{array}$ & $\begin{array}{c}1.125 \\
(4.875)\end{array}$ & $\begin{array}{l}11.43 * * * \\
(3.983)\end{array}$ & $\begin{array}{l}-3.384 \\
(3.783)\end{array}$ & $\begin{array}{l}-1.277 \\
(6.003)\end{array}$ & $\begin{array}{l}-11.95^{* *} \\
(4.799)\end{array}$ \\
\hline SD of stock index & $\begin{array}{c}0.000 \\
(0.000)\end{array}$ & $\begin{array}{c}0.000 \\
(0.000)\end{array}$ & $\begin{array}{l}-0.000 \\
(0.000)\end{array}$ & $\begin{array}{l}-0.000 \\
(0.000)\end{array}$ & $\begin{array}{c}-0.000 \\
(0.000)\end{array}$ & $\begin{array}{l}0.000 * \\
(0.000)\end{array}$ \\
\hline SD of unemployment rate & $\begin{array}{l}0.328 * \\
(0.169)\end{array}$ & $\begin{array}{c}0.106 \\
(0.228)\end{array}$ & $\begin{array}{c}0.245 \\
(0.173)\end{array}$ & $\begin{array}{l}-0.167 \\
(0.228)\end{array}$ & $\begin{array}{c}0.236 \\
(0.292)\end{array}$ & $\begin{array}{l}-0.178 \\
(0.230)\end{array}$ \\
\hline SD of inflation & $\begin{array}{l}-27.83 \\
(42.10)\end{array}$ & $\begin{array}{c}6.901 \\
(50.13)\end{array}$ & $\begin{array}{l}-35.30 \\
(39.12)\end{array}$ & $\begin{array}{c}25.26 \\
(40.96)\end{array}$ & $\begin{array}{c}91.74 \\
(74.70)\end{array}$ & $\begin{array}{l}-31.27 \\
(52.37)\end{array}$ \\
\hline N observations & 524 & 496 & 517 & & & \\
\hline $\mathrm{N}$ country-country id & 215 & 207 & 213 & & & \\
\hline $\mathrm{N}$ instruments & 299 & 252 & 252 & & & \\
\hline AR (1) p-value & 0.03 & 0.00 & 0.03 & & & \\
\hline AR (2) p-value & 0.96 & 0.37 & 0.09 & & & \\
\hline Hansen p-value & 1.00 & 1.00 & 0.99 & & & \\
\hline
\end{tabular}

Robust standard errors are in parentheses $* * * \mathrm{p}<0.01, * * \mathrm{p}<0.05, * \mathrm{p}<0.1$ 
Table 16. Portfolio investments, 2007-10, share equal to or above 7 percent

\begin{tabular}{|c|c|c|c|c|c|c|}
\hline \multirow[b]{2}{*}{ VARIABLES } & \multicolumn{3}{|c|}{ high concentration } & \multicolumn{3}{|c|}{ Interaction term } \\
\hline & $\begin{array}{l}\text { total } \\
(1)\end{array}$ & $\begin{array}{c}\text { equity } \\
\text { (2) }\end{array}$ & $\begin{array}{l}\text { debt } \\
(3)\end{array}$ & $\begin{array}{l}\text { total } \\
(4)\end{array}$ & $\begin{array}{c}\text { equity } \\
(5)\end{array}$ & $\begin{array}{l}\text { debt } \\
(6)\end{array}$ \\
\hline portfoli investment & $\begin{array}{c}0.891 * * * \\
(0.027)\end{array}$ & $\begin{array}{c}0.962 * * * \\
(0.031)\end{array}$ & $\begin{array}{c}0.903 * * * \\
(0.033)\end{array}$ & - & - & - \\
\hline short-term interest rate & $\begin{array}{c}-0.176^{*} \\
(0.106)\end{array}$ & $\begin{array}{c}0.146 \\
(0.145)\end{array}$ & $\begin{array}{c}-0.203 * \\
(0.122)\end{array}$ & $\begin{array}{c}0.160 \\
(0.103)\end{array}$ & $\begin{array}{l}-0.155 \\
(0.143)\end{array}$ & $\begin{array}{c}0.178 \\
(0.122)\end{array}$ \\
\hline long-term interest rate & $\begin{array}{c}0.343 \\
(0.275)\end{array}$ & $\begin{array}{l}-0.069 \\
(0.355)\end{array}$ & $\begin{array}{c}0.473 \\
(0.330)\end{array}$ & $\begin{array}{l}-0.164 \\
(0.268)\end{array}$ & $\begin{array}{l}-0.040 \\
(0.372)\end{array}$ & $\begin{array}{c}-0.242 \\
(0.335)\end{array}$ \\
\hline stock index & $\begin{array}{l}0.000^{*} \\
(0.000)\end{array}$ & $\begin{array}{c}0.000 \\
(0.000)\end{array}$ & $\begin{array}{c}0.000 \\
(0.000)\end{array}$ & $\begin{array}{l}-0.000^{*} \\
(0.000)\end{array}$ & $\begin{array}{l}-0.000 \\
(0.000)\end{array}$ & $\begin{array}{l}-0.000 \\
(0.000)\end{array}$ \\
\hline growth of stock index & $\begin{array}{c}6.573 \\
(9.343)\end{array}$ & $\begin{array}{c}13.99 \\
(9.985)\end{array}$ & $\begin{array}{c}0.366 \\
(9.899)\end{array}$ & $\begin{array}{c}-8.527 \\
(7.695)\end{array}$ & $\begin{array}{l}-17.55^{*} \\
(9.167)\end{array}$ & $\begin{array}{l}-3.965 \\
(9.150)\end{array}$ \\
\hline unemployment rate & $\begin{array}{c}0.099 \\
(0.071)\end{array}$ & $\begin{array}{c}0.013 \\
(0.021)\end{array}$ & $\begin{array}{c}0.106 \\
(0.073)\end{array}$ & $\begin{array}{l}-0.092 \\
(0.070)\end{array}$ & $\begin{array}{c}0.003 \\
(0.029)\end{array}$ & $\begin{array}{l}-0.105 \\
(0.072)\end{array}$ \\
\hline inflation & $\begin{array}{l}-38.29 \\
(23.97)\end{array}$ & $\begin{array}{l}-22.09 \\
(28.71)\end{array}$ & $\begin{array}{l}-29.58 \\
(23.53)\end{array}$ & $\begin{array}{c}39.92 \\
(27.57)\end{array}$ & $\begin{array}{c}24.25 \\
(28.90)\end{array}$ & $\begin{array}{c}23.23 \\
(27.05)\end{array}$ \\
\hline real effective exchange rate & $\begin{array}{l}-0.009 \\
(0.009)\end{array}$ & $\begin{array}{l}-0.001 \\
(0.012)\end{array}$ & $\begin{array}{l}-0.014 \\
(0.011)\end{array}$ & $\begin{array}{l}0.006 \\
(0.009)\end{array}$ & $\begin{array}{c}0.021 \\
(0.014)\end{array}$ & $\begin{array}{c}0.009 \\
(0.011)\end{array}$ \\
\hline GDP growth & $\begin{array}{c}6.421 \\
(6.086)\end{array}$ & $\begin{array}{c}8.776 \\
(6.812)\end{array}$ & $\begin{array}{c}6.500 \\
(8.002)\end{array}$ & $\begin{array}{l}-2.906 \\
(4.406)\end{array}$ & $\begin{array}{l}-10.09^{*} \\
(5.535)\end{array}$ & $\begin{array}{l}-3.206 \\
(6.453)\end{array}$ \\
\hline $\begin{array}{l}\text { current account to GDP } \\
\text { ratio }\end{array}$ & $\begin{array}{l}-4.872 \\
(3.427)\end{array}$ & $\begin{array}{c}2.149 \\
(3.660)\end{array}$ & $\begin{array}{l}-4.243 \\
(3.959)\end{array}$ & $\begin{array}{l}4.225 \\
(3.578)\end{array}$ & $\begin{array}{l}-2.081 \\
(3.581)\end{array}$ & $\begin{array}{c}3.550 \\
(4.093)\end{array}$ \\
\hline $\begin{array}{l}\text { government debt to GDP } \\
\text { ratio }\end{array}$ & $\begin{array}{l}-2.027^{*} \\
(1.056)\end{array}$ & $\begin{array}{c}0.106 \\
(0.730)\end{array}$ & $\begin{array}{l}-1.870 \\
(1.137)\end{array}$ & $\begin{array}{c}1.563 \\
(1.048)\end{array}$ & $\begin{array}{l}-0.207 \\
(0.719)\end{array}$ & $\begin{array}{c}1.416 \\
(1.144)\end{array}$ \\
\hline $\begin{array}{l}\mathrm{SD} \text { of short-term interest } \\
\text { rate }\end{array}$ & $\begin{array}{c}0.542 \\
(0.534)\end{array}$ & $\begin{array}{c}0.074 \\
(0.632)\end{array}$ & $\begin{array}{c}0.833 \\
(0.581)\end{array}$ & $\begin{array}{l}-0.290 \\
(0.486)\end{array}$ & $\begin{array}{l}-0.009 \\
(0.661)\end{array}$ & $\begin{array}{l}-0.430 \\
(0.519)\end{array}$ \\
\hline $\begin{array}{l}\text { SD of long-term interest } \\
\text { rate }\end{array}$ & $\begin{array}{l}-0.477 \\
(0.490)\end{array}$ & $\begin{array}{c}0.199 \\
(0.746)\end{array}$ & $\begin{array}{l}-0.721 \\
(0.596)\end{array}$ & $\begin{array}{c}0.440 \\
(0.481)\end{array}$ & $\begin{array}{l}-0.113 \\
(0.776)\end{array}$ & $\begin{array}{c}0.934 \\
(0.641)\end{array}$ \\
\hline SD of stock index growth & $\begin{array}{c}3.645 \\
(6.938)\end{array}$ & $\begin{array}{c}5.742 \\
(9.027)\end{array}$ & $\begin{array}{c}2.742 \\
(7.885)\end{array}$ & $\begin{array}{l}-4.929 \\
(8.076)\end{array}$ & $\begin{array}{l}-11.68 \\
(9.269)\end{array}$ & $\begin{array}{l}-5.732 \\
(9.014)\end{array}$ \\
\hline SD of stock index & $\begin{array}{l}0.000^{*} \\
(0.000)\end{array}$ & $\begin{array}{c}0.000 \\
(0.000)\end{array}$ & $\begin{array}{c}0.000 \\
(0.000)\end{array}$ & $\begin{array}{l}-0.000 \\
(0.000)\end{array}$ & $\begin{array}{l}-0.000 \\
(0.000)\end{array}$ & $\begin{array}{l}-0.000 \\
(0.000)\end{array}$ \\
\hline SD of unemployment rate & $\begin{array}{l}-0.375 \\
(0.425)\end{array}$ & $\begin{array}{c}0.233 \\
(0.303)\end{array}$ & $\begin{array}{l}-0.297 \\
(0.399)\end{array}$ & $\begin{array}{c}0.370 \\
(0.391)\end{array}$ & $\begin{array}{l}-0.375 \\
(0.358)\end{array}$ & $\begin{array}{c}0.291 \\
(0.361)\end{array}$ \\
\hline SD of inflation & $\begin{array}{l}-18.94 \\
(54.79)\end{array}$ & $\begin{array}{r}234.6^{* *} \\
(97.19) \\
\end{array}$ & $\begin{array}{l}-74.26 \\
(67.05) \\
\end{array}$ & $\begin{array}{r}-50.39 \\
(62.24) \\
\end{array}$ & $\begin{array}{l}-124.1 \\
(101.0) \\
\end{array}$ & $\begin{array}{l}-24.06 \\
(71.01) \\
\end{array}$ \\
\hline $\mathrm{N}$ observations & 251 & 251 & 251 & & & \\
\hline $\mathrm{N}$ country-country id & 97 & 97 & 97 & & & \\
\hline $\mathrm{N}$ instruments & 133 & 133 & 133 & & & \\
\hline AR (1) p-value & 0.11 & 0.11 & 0.08 & & & \\
\hline AR (2) p-value & 0.36 & 0.83 & 0.54 & & & \\
\hline Hansen p-value & 0.99 & 1.00 & 0.99 & & & \\
\hline
\end{tabular}

Robust standard errors are in parentheses $* * * \mathrm{p}<0.01, * * \mathrm{p}<0.05, * \mathrm{p}<0.1$ 


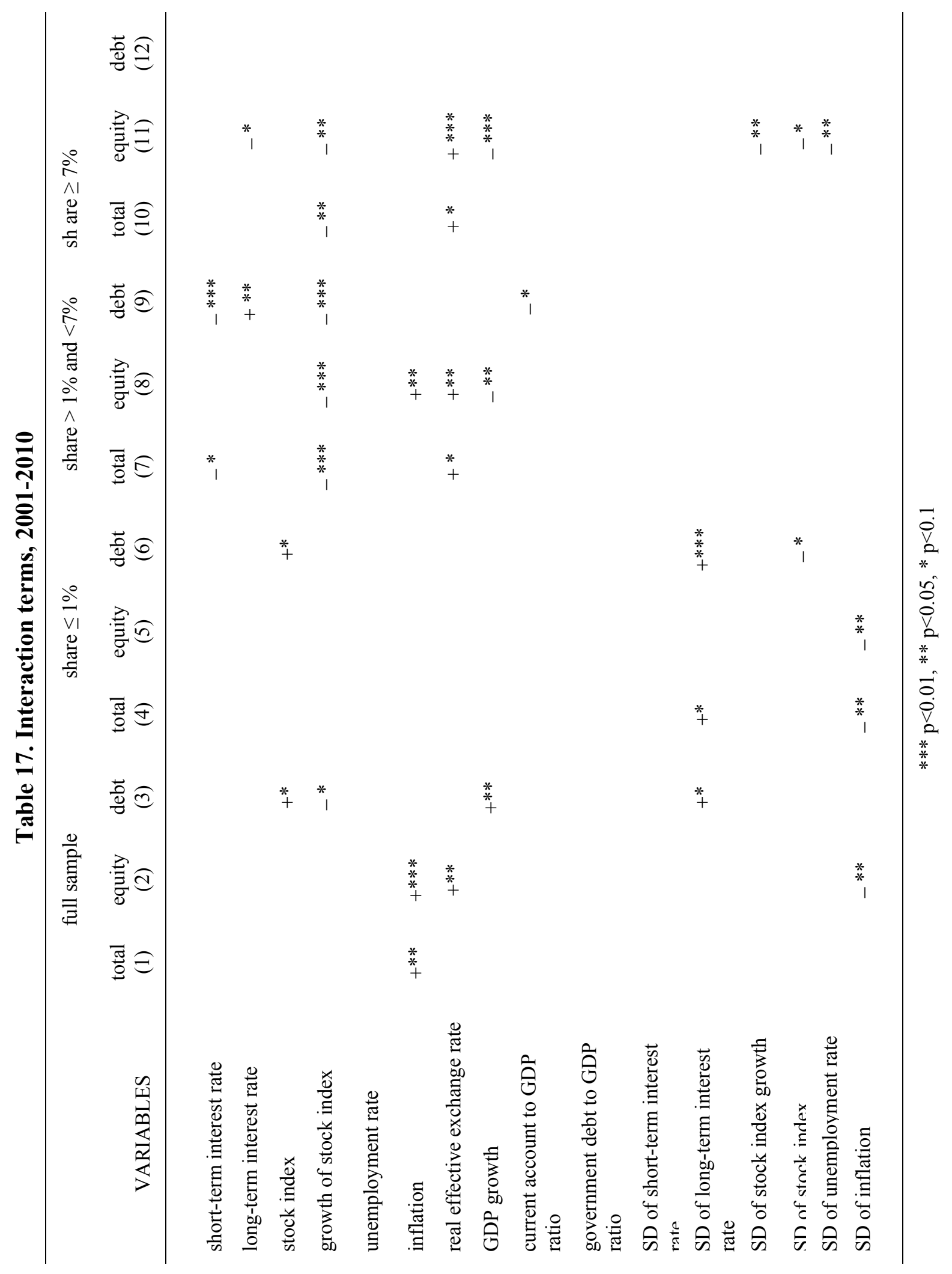




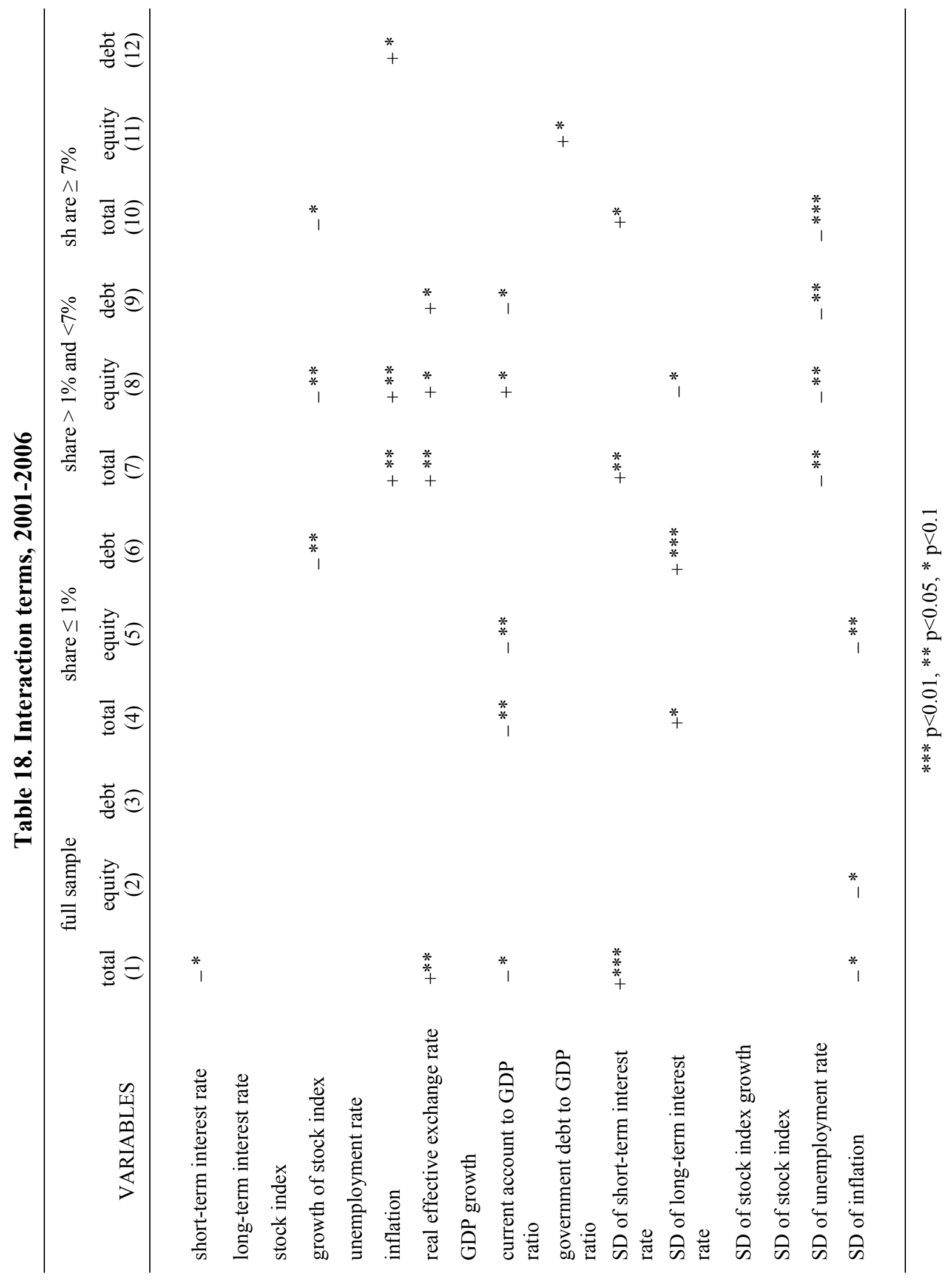




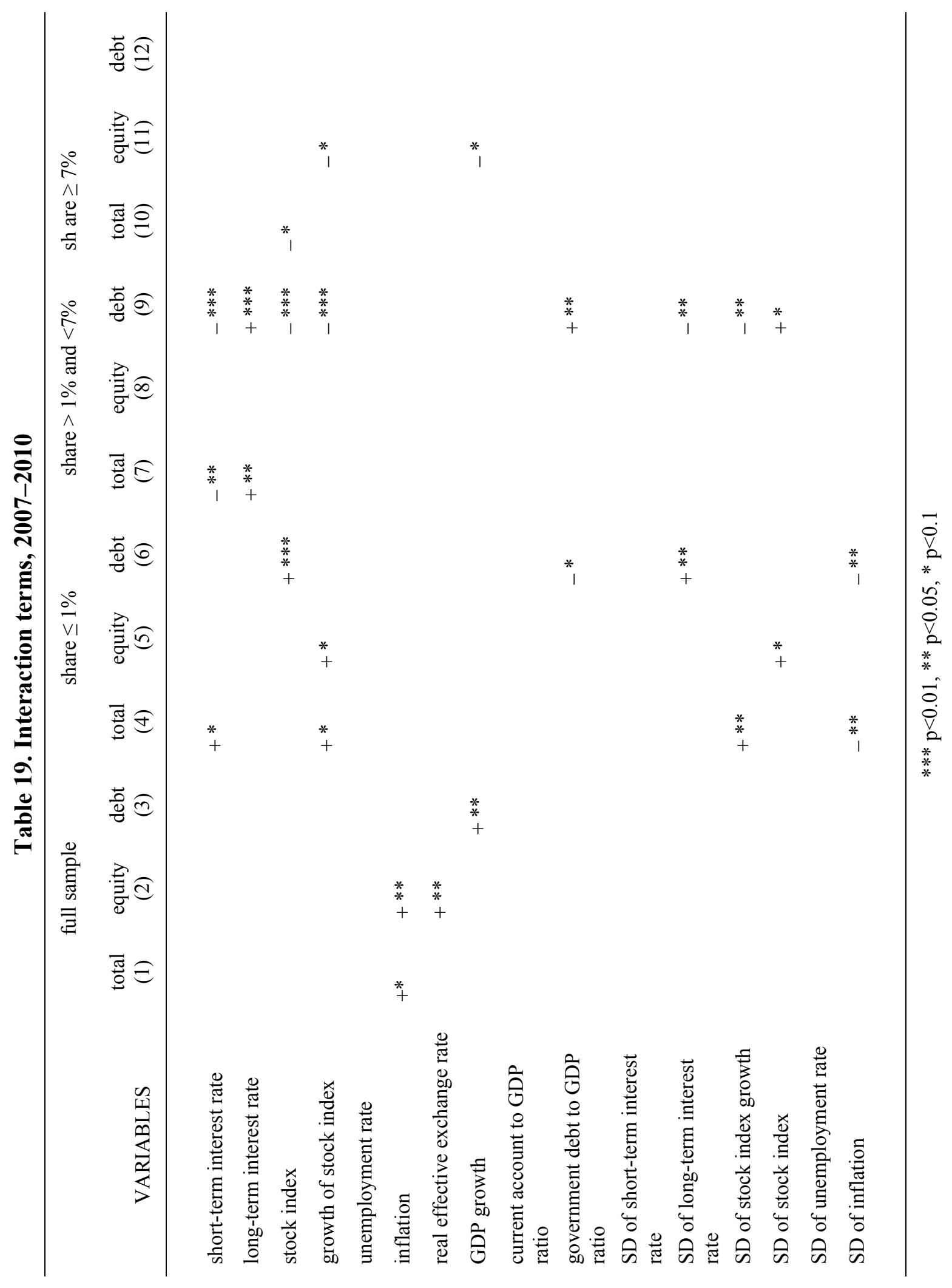

